\title{
Ulisse Aldrovandi's Color Sensibility: Natural History, Language and the Lay Color Practices of Renaissance Virtuosi
}

\author{
Valentina Pugliano \\ University of Cambridge \\ vp261@cam.ac.uk·
}

\begin{abstract}
Famed for his collection of drawings of naturalia and his thoughts on the relationship between painting and natural knowledge, it now appears that the Bolognese naturalist Ulisse Aldrovandi (1522-1605) also pondered specifically color and pigments, compiling not only lists and diagrams of color terms but also a full-length unpublished manuscript entitled $D e$ coloribus or Trattato dei colori. Introducing these writings for the first time, this article portrays a scholar not so much interested in the materiality of pigment production, as in the cultural history of hues. It argues that these writings constituted an effort to build a language of color, in the sense both of a standard nomenclature of hues and of a lexicon, a dictionary of their denotations and connotations as documented in the literature of ancients and moderns. This language would serve the naturalist in his artistic patronage and his natural historical studies, where color was considered one of the most reliable signs for the correct identification of specimens, and a guarantee of accuracy in their illustration. Far from being an exception, Aldrovandi's 'color sensiblity' spoke of that of his university-educated natureloving peers.
\end{abstract}

\section{Keywords}

Ulisse Aldrovandi - De coloribus - color terminology - uroscopy - scientific illustration

- University of Cambridge, Department of History and Philosophy of Science, Free School Lane, Cambridge C2 3RH, UK. I would like to express my sincere thanks to Miranda Stanyon, Caroline Vout, Bernardo Zacka and the editors, for their help in revising this article. 


\section{Introduction}

On the essence of color. Whether an accident possesses in itself something essential.

- Julius Caesar Scaliger, Exotericarum exercitationum liber $X V$. (1557), Exercitatio $\operatorname{cccxxv}$.

In 1580, the Bolognese naturalist Ulisse Aldrovandi recalled how thirty years earlier, as a young man, he had descended into a set of caves lying underneath the Esquiline Hill in Rome. With "light and rope so as not to get lost," he had made his way down to inspect the "infinite beautiful paintings made from life, and grotesques" that had been rediscovered a century earlier near the Basilica of San Pietro in Vincoli, quickly becoming a popular destination for curious gentlemen and artists alike. ${ }^{1}$ Aldrovandi had nurtured an interest in the art and antiquities of Rome ever since he was forcibly taken there to be tried for heresy in 1549 . Released a year later, he would always conceal this incident from the public narrative of his life. Yet, the occasion had also afforded him several months to explore sights that left a mark on his future interests, from ruins and fishmarkets to the new sculpture gardens of the clergy. ${ }^{2}$ The older Aldrovandi did not recall this speleological episode to celebrate Rome's visual wealth, however, but to refute the opinion of his close friend Cardinal Gabriele Paleotti that painting was more ancient than script. This was doubtful in Aldrovandi's view. Grotesques after all were no older than the Romans themselves, "otherwise Vitruvius would make reference to this." ${ }^{3}$ They could not be compared to Assyrian letters which, Pliny testified, "have always existed," nor to the astronomical observations inscribed on "fired bricks" by the

\footnotetext{
${ }^{1}$ As Aldrovandi noted, these were the remains of Nero's Domus Aurea, Bologna, Biblioteca Universitaria Bologna, Aldrovandi Ms 6/II, 97r-105v, "Lettera di Ulisse Aldrovandi al Cardinale Paleotti sulle grottesche" (6 Dec 1580), fol. 102r. Biblioteca Universitaria Bologna is henceforth referred to as BUB.

${ }^{2}$ The latter famously prompted Tutte le statue antiche, che in Roma da ogni parte si vedono, appended to Lucio Mauro, Le antichità della città di Roma (Venice, 1556), and reprinted several times. Conceived as a comprehensive guide to the collections of "ancient statuary sculpted from peregrine marbles" in Rome, this is the only full-length treatise Aldrovandi devoted to antiquities and the artwork of contemporaries. See Daniela Gallo, "Ulisse Aldrovandi, le statue di Roma e i marmi romani," Mélanges de l'Ecole française de Rome. Italie et Méditerranée, 104 (2) (1992), 479-90.

${ }^{3}$ BUB, Aldrovandi MS 6/II, fols. 101v-102r.
} 
venerable Babylonians. ${ }^{4}$ Not to mention the insight supplied by etymology: writing and painting shared the same tools and the same word $\gamma \rho \alpha \varphi \varepsilon ́ l v(<$ graph'ein>), at its most basic meaning 'to leave a mark on a surface', a clear clue for Aldrovandi that script came first. Since books were more ancient, he concluded, "they should be praised more.",5

This anecdote not only foregrounds a concern with forms of communication and language that will be this article's focus, but also encapsulates that complex process of triangulation between fieldwork, art and texts that shaped Aldrovandi's intellectual work throughout his life and arguably also that of many of his contemporaries. This triangulation, in Aldrovandi's case, meant that the empirical approach to the study of nature and artifacts was mediated by a strong reliance on textual knowledge, which could turn the analysis of the object into a rhetorical exercise and a display of antiquarian erudition. ${ }^{6}$ It also meant that art, while considered capable of producing delightful results, was a secondary form of expression which the scholar could bring to his aid but towards which he would always harbour some diffidence. This epistemological sensibility plays a strong part in the story of art and science that follows.

Historians of science and art have long assigned Aldrovandi a privileged place in the history of scientific illustration and collecting, both for his commitment to empiricism and for the scale of his patronage (Fig. 1). ${ }^{7}$ He had already achieved fame among his contemporaries thanks in no small part to his Theater of Nature, one of the largest museums of naturalia in early modern Europe. Integral to this collection were pencil drawings, watercolors and woodcut blocks portraying the physical specimens that filled the museum and provided the raw material for his botanical and zoological studies. They were the output of what Giuseppe Olmi calls his "artistic workshop," a host of artists of varying talent whom Aldrovandi employed over a period of five decades. Some spent years as part of his household, others were only passing contacts. Yet on his death in 1605, their production amounted to some

\footnotetext{
${ }^{4}$ Ibid., 108r-117r, "Lettera a Paleotti sopra ai capitoli sulla pittura" (5 Jan 1581), fols. 108r-109r.

${ }^{5}$ Ibid., 119r-128v, "Seconda lettera a Paleotti sopra ai capitoli sulla pittura" (20 Jan 1581), fols. 120r-v.

${ }^{6}$ Paula Findlen, Possessing Nature: Museums, Collecting, and Scientific Culture in Early Modern Italy (Berkeley, 1994), 48-57.

${ }^{7}$ Giuseppe Olmi, “Osservazione della natura e raffigurazione in Ulisse Aldrovandi (1522-1605)," Annali dell'Istituto Storico Germanico Italiano a Trento, 3 (1977), 105-81; Giuseppe Olmi, Lucia Tongiorgi Tomasi, Alessandro Zanca, eds., Natura=Cultura. L'interpretazione del mondo fisico nei testi e nelle immagini (Florence, 2000).
} 
eighteen volumes containing 4,000 images of plants and 3,000 images of animals and minerals allegedly painted from life. ${ }^{8}$

It is well known that Aldrovandi's career as a patron was accompanied by frequent reflections on the relationship between painting and natural knowledge, between the art of representation and the truth of nature. Less known is that he also began to ponder pigments and colors more specifically, and to a smaller degree the materials from which these derived. To my delight, during my last visit to the Aldrovandi archive in Bologna I stumbled upon an unpublished manuscript of his, a Trattato dei colori, which despite its title is written in Latin and is elsewhere referred to as De coloribus (MS 72) (Fig. 2). This treatise fills one of those long and narrow volumes bound in calfskin in which the naturalist regularly used to jot down his drafts. Belying its title, it is not a commentary on the pseudo-Aristotelian De coloribus, as contemporaries of Aldrovandi were writing. ${ }^{9}$ Its appearance is that of a commonplace book, which gathers excerpts on the topic of color from existing treatises. Six pages detailing the "loca" under which such information is filed and a list of cited authors close the manuscript. ${ }^{10}$ Further digging among Aldrovandi's papers uncovered two related sets of notes in separate volumes. MS 95 contains four pages enumerating ninety-four colors, each listed by its Latin name, or the Latinized version of its Greek appellation, and explained with a phrase in the vernacular, from the white Albus to Ater, the deepest black (Fig. 3). MS 40 contains a set of diagrams in Latin which expand on the previous glossary and reorganize its nomenclature around the seven-color scale attributed to Aristotle (Fig. 4). ${ }^{11}$ While dating these writings or establishing their order of composition is not straightforward, they were likely produced between the $1560 \mathrm{~s}$ and $1580 \mathrm{~s}^{12}$

This article provides a first introduction to these works, investigating the reasons behind their composition and their probable uses. Little of a comparable nature has survived among the papers of contemporary naturalists. Yet their value is not limited to this status of textual relic. My contention is that they should be taken as a window on the lay color

\footnotetext{
${ }^{8}$ BUB, Aldrovandi MS 97, fols. 675r-676v, "Discorso breve dell'opere del signor Ulisse Aldrovandi," fols. $675 \mathrm{r}-\mathrm{v}$.

${ }^{9}$ See n. 28.

${ }^{10}$ BUB, Aldrovandi MS 72, "Trattato de colori," fols. 155r-163r.

${ }^{11}$ Ibid.; MS 95, fols. 359r-360v, untitled; MS 40, fols. 118r-121r, untitled. These writings have escaped scholarly attention, despite featuring in Lodovico Frati's Catalogo dei manoscritti di Ulisse Aldrovandi (Bologna, 1907).

${ }^{12}$ For MS 95, we can summon an unreliable witness: a broadsheet pasted just after the list depicting prodigies that appeared in Caffa, on the Black Sea, on January 6, 1567 (fol. 361r) (see Fig. 5).
} 
practices of Renaissance virtuosi, individuals like Aldrovandi who did not belong to the art trades or produce visual artifacts (they often did not even sketch), ${ }^{13}$ but who increasingly felt the need for a mode of analysis in their studies different from script, and became consumers and patrons of art. Overall the content of these writings is neither original nor particularly unusual. Aldrovandi is not proposing a personal color theory nor, despite some tinkering, a novel color nomenclature, but instead relies for the former on widespread notions taken from Aristotelian and Platonic philosophy, and for the latter on select humanist publications. ${ }^{14}$ Yet, while bookish, his writings were more practical than they appear and illuminate theoretical concerns and practical obstacles that most collectors and naturalists faced in the period.

These texts confirm that color had a central place in the identification and classification of naturalia, one it would only lose, according to David Freedberg, when a more streamlined taxonomic system based on morphological characteristics gained ground in the eighteenth century. ${ }^{15}$ However, while considered one of the essential notae or characteristics of a specimen, color was notoriously difficult to pin down. Not only did individuals perceive hues differently, but how best to articulate this perception verbally remained an open question. ${ }^{16}$ So did the issue of communicating the variety of colors to others, particularly when this communication occurred without the specimen, via letter or a black-and-white paragraph in print. The terminology inherited from classical textsespecially those in Latin, a language where color, as Michael Baxandall notes, was a "category of visual interest fully developed"- had lost its clarity. ${ }^{17}$ Meanings had shifted and many referents had become culturally obsolete, leaving their Renaissance users unsure of how exactly names matched chromatic variation. ${ }^{18}$ Vernacular renderings used in everyday

\footnotetext{
${ }^{13}$ Aldrovandi had allegedly "delighted himself" in drawing in his youth. BUB, Aldrovandi MS 91, 503r-559r, "Discorso Naturale nel quale si tratta in generale del suo Museo," fol. 557; this text is henceforth referred to as Discorso.

${ }^{14}$ On ancient color theories, see Maria Michela Sassi, "Entre corps et lumière: Réflexions antiques sur la nature de la couleur," in L'antiquité en couleurs: catégories, pratiques, représentations, ed. Marcello Carastro (Grenoble, 2009), 277-300.

${ }^{15}$ David Freedberg, "The Failure of Colour," in Sight and Insight: Essays on Art and Culture in Honour of E.H. Gombrich, ed. John Onians (London, 1994), 245-62.

${ }^{16}$ For an overview, see Carole P. Biggam, The Semantics of Colour: A Historical Approach (Cambridge, 2012).

${ }^{17}$ Michael Baxandall, Giotto and the Orators: Humanist Observers of Painting in Italy and the Discovery of Pictorial Composition 1350-1450 (Oxford, 1971), 48-9.

${ }^{18}$ See John Gage, Colour and Culture: Practice and Meaning from Antiquity to Abstraction (London, 1995), 11$38,79-80$.
} 
parlance and in artists' workshops added a layer of difficulty. ${ }^{19}$ What Aldrovandi's manuscripts do, I argue, is precisely address this fluidity of language, this man-made ambiguity of color. This is the lay color practice I will discuss here in relation to scientific illustration. While historians have touched upon the significance of color in the visual technologies of early modern natural history, ${ }^{20}$ this investment in a chromatic language and the extensive influence exercised on naturalists by the flourishing humanist genre of color etymology, remain very much in need of further consideration.

\section{"Russam gingivam dixit Catullus"21}

Aldrovandi's MS 72 De coloribus belongs to the well-established genre of the commonplace book, serving as a reading exercise and a communion with textual authorities in the humanist matrix. $^{22}$ The information is presented under categories designed to reconstruct the microcosm of a given hue - its name, symbolism, attributes and uses - as well as to enable a theoretical overview of the category of color itself. Generally no longer than a couple of lines, the entries consist of short quotations and summarized passages with references that send the reader to the original source, as these examples illustrate:

Cause. The fiery igneus color has its origin in the sun. Ceruleus in the cloud. Seneca $229 .^{23}$

Transformation. Colors change. Theophrastus wrote one book about those [factors] that make colors change. See Diogenes Laertium, fol. $203{ }^{24}$

\footnotetext{
${ }^{19}$ See Oltrogge's essay in this volume.

${ }^{20}$ Olmi, "Osservazione della natura"; Freedberg, "The Failure of Colour"; Sachiko Kusukawa, Picturing the Book of Nature: Image, Text and Argument in Sixteenth-Century Human Anatomy and Medical Botany (Chicago, 2012), 63-80.

${ }^{21}$ Julius Caesar Scaliger, Exotericarum exercitationum liber XV. (1557), fol. 440v.

${ }^{22}$ See Ann Blair, Too Much to Know: Managing Scholarly Information Before the Modern Age (New Haven, 2010), 117-72.

23 “Causa. Color igneus a sole est. Ceruleus a nube. Seneca phil. 229.” BUB, Aldrovandi MS 72, fol. 58r.

24 "Mutatio. Colores mutantur. Theophrastus scripsit librum unum de his qua colores immutant[ur]. Vide Diog. Laertium fol. 203.” Ibid., fol. 59r.
} 
Denominated. Color caducus, Ercole Bentivoglio. Satire 1. "And because of a glance, adorned on a woman's visage graced by a transient glow, [Man] loses his wit, and, shamefully, his freedom., 25

Use. Yellow (luteus) color and its livery.

Araldo, De colore, sig. $21 .^{26}$

Remedies. Curative properties are attributed to foul colors, as when [the body] produces black bile.

Laurentius Hubertus, De peste. ${ }^{27}$

Milky (lacteus) color. Signifies. A commendable color signifying the steady fortitude that is born from temperance. ${ }^{28}$

India possesses many colors.

Strabo, Book $15 .^{29}$

The categories used to discuss the differentiae between color iterations originate in Aristotelian logic and natural philosophy, on which Aldrovandi had lectured at length at the start of his academic career in Bologna. ${ }^{30}$ The pool of Aristotelian distinctions, however, is enlarged to satisfy the encyclopedic taste of the period. Thus traditional analytical categories such as 'Species', 'Definition', 'Generation', 'Action', 'Faculty', 'Cause', 'Sympathy and antipathy' are complemented by rhetorical ones such as 'Epithets', 'Proverbs', 'Synonyms', as well as 'Mystical' and 'Prognostications'. This is a method of structuring and communicating knowledge that recurs across Aldrovandi's works, notably in zoological treatises like the Ornithologia (1599-1600), leading scholars to speak of the emblematic

\footnotetext{
25 “Denominatum. Color caducus, Hercole Bentevoy. Satyr. 1. 'Et per un volger d'occhi et con adorno - Di caduco color feminil sul viso, perde il saper, la libertà con scorno'.” Ibid., fol. 37r.

26 “Usus. Color luteus et sua livrea. Arald. De colore 21.” Ibid., fol. 67r.

27 "Remedia. Coloribus faedis adtributa remedia, quandoque atram bilem procreat. Lauren. Hubert. De peste." Ibid., fol. 91r.

28 “Color lacteus. Significans. Color bonus et constans valitudo ex temperantia oritur” Ibid., fol. 36r.

29 "Colores multos habet India. Strabo lib. 15" Ibid., fol. 93r.

${ }^{30}$ Ibid., MS 91, 503r-559r, Discorso, fol. 507v; Sandra Tugnoli-Pattaro, Metodo e sistema delle scienze nel pensiero di Ulisse Aldrovandi (Bologna, 1981).
} 
worldview of Renaissance natural history. ${ }^{31}$ The concern is for the 'cultural' over the material attributes of colors. The manuscript contains no recipes or similar instructions for the mixing of pigments. Loci prospected in the index promising an insight into workshop practice - such as "Colours used by painters" and "Ratio of colors for dyeing"- are not necessarily followed through. ${ }^{32}$ More common are references to the uses of colors in art and society at large, which, however, remain usually formulaic: for example, quoting Cicero's De legibus, Aldrovandi notes that white is especially approriate to render the divine. ${ }^{33}$

Accordingly, rather than by reaching out to the words and shops of artists, pigmentsellers and dyers, Aldrovandi extracts this wealth of information from the omnivorous contents of his library. ${ }^{34}$ Treating color mostly incidentally, the titles referenced in MS 72 easily reach one hundred and address an extraordinary breadth of topics in both verse and prose including theology, philosophy, theoretical and practical medicine, heraldry, geography and travel. Canonical authors from antiquity like Virgil, Vitruvius, Suetonius and Horace sit next to more recent authorities like Bartholomaeus Anglicus, Petrarch, Marsilio Ficino and Gianbattista Della Porta. Exemplifying the eclecticism of the Renaissance scholar and the compilatory research methodology of the scholastics, core sources include the commentaries on Aristotle's Meteorology by Alexander of Aphrodisias, source of a dominant philosophical current in the Paduan studium, where Aldrovandi was initiated into the study of philosophy and logic; ${ }^{35}$ Julius Caesar Scaliger's Exotericarum Exercitationum liber XV. (Paris, 1557), whose lengthy Exercise 325 was devoted to color etymology; ${ }^{36}$ a bestseller for learned

\footnotetext{
${ }^{31}$ William B. Ashworth, "Natural History and the Emblematic Worldview," in Reappraisals of the Scientific Revolution, eds. David C. Lindberg and Robert S. Westman (Cambridge, 1990), 303-32.

${ }^{32}$ See BUB, Aldrovandi MS 72, fols. 155r-163r.

${ }^{33}$ Ibid., $15 \mathrm{r}$.

${ }^{34}$ On Aldrovandi's bibliophilia, see Irene Ventura Folli, “La natura 'scritta': La 'libraria' di Ulisse Aldrovandi (1522-1605)," in Bibliothecae selectae: Da Cusano a Leopardi, ed. Eugenio Canone (Florence, 1993), $495-506$. For a parallel, Urs B. Leu, Raffael Keller and Sandra Weidmann, Conrad Gessner's Private Library (Leiden, 2008).

${ }^{35}$ Tugnoli-Pattaro (1981), Metodo e sistema, 33-5.

${ }^{36}$ On the esteem enjoyed by Scaliger among early modern natural philosophers, see Ian Maclean, "The Interpretation of Natural Signs: Cardano's De subtilitate versus Scaliger's Exercitationes," in Occult and Scientific Mentalities, ed. Brian Vickers (Cambridge, 1984), 231-52.
} 
gentlemen, Pasquale Caracciolo's La gloria del cavallo (Naples, 1566); and a book purchased at the Giunti printers in Florence on the colors of arms, liveries and uniforms. ${ }^{37}$

Though Aldrovandi did not go out of his way to acquire texts specifically on colors and the treatment of pigments, we find sporadic references to Leon Battista Alberti's De pictura (1435), whose Book One examined the question of light and darkness and the generation of colors from black and white; and Simone Porzio's De coloribus libellus (1548), a commentary of the pseudo-Aristotelian De coloribus largely concerned with a theoretical discussion of optics. ${ }^{38}$ Nonetheless, there are two conspicuous absences on Aldrovandi's bookshelf. One is the vernacular Fachliteratur, especially the so-called 'books of secrets' which contained numerous recipes for the preparation of pigments, dyes, cosmetic powders and hair colorants and which were meeting with great success in the Italian print market. An exception is Girolamo Ruscelli's Segreti di Alessio Piemontese, a Renaissance bestseller which, keeping in line with the erudite bent of MS 72, Aldrovandi read in the Latin translation of a colleague, the Basel physician Johann Jacob Wecker. ${ }^{39}$ Absent also is alchemical literature, generally marginal to Aldrovandi's interests, yet where color occupied an important place both for the symbolic meanings it carried (albedo, nigredo, rubedo and citrinitas defined the four main stages of transmutation in the quest for the magnus opus), and as a practical marker that allowed the artifex to discern and describe changes in the materials handled during workshop operations. ${ }^{40}$

Plentiful, instead, are medical texts, from the medieval Canon of Avicenna and Sante Arduino's De venenis (1492) to contemporary works like Girolamo Cardano on the Aphorisms of Hippocrates, Wecker's Medicae syntaxes (1562), Gabriele Falloppio's De medicatis aquis (1564) and Girolamo Mercuriale's De morbis cutaneis (1572). This is a reflection both of Aldrovandi's medical education, and of the prognostic and diagnostic importance of colors in medicine and surgery, where they were used to qualify symptoms and

\footnotetext{
${ }^{37}$ Sicillo, Araldo del Re Alfonso V d'Aragona [= Sicile, Herald to King Alfons V of Aragon], Trattato dei colori nelle arme, nelle livree et nelle divise (Venice, 1565).

${ }^{38}$ A Neapolitan physician and professor of natural philosophy, Porzio also wrote De coloribus oculorum (Florence, 1550) on the anatomy, perception, and appearance of the human eye. See Eva Del Soldato, Simone Porzio: Un aristotelico tra natura e grazia (Rome, 2010).

${ }^{39}$ Johann Jacob Wecker, De secretis libri (Basel, 1560). See William Eamon, Science and the Secrets of Nature: Books of Secrets in Medieval and Early Modern Culture (Princeton, 1994).

${ }^{40}$ Lawrence Principe, The Secrets of Alchemy (Chicago, 2012).
} 
signs, such as bodily discharges and outward changes in a patient's complexion. ${ }^{41}$ Colors were especially crucial in the practices of haematoscopy, centered around the examination of blood, and uroscopy, whereby physicians assessed their patients' humoral balance and the severity of their illness by inspecting the tint of their urine and often tasting it as well. ${ }^{42}$ To aid doctors in this practice, there had since the medieval period been textual tools, including 'urine wheels' and tables classifying minutely the color variation in human urine (Fig. 6). ${ }^{43}$ Next to medical texts, MS 72 references volumes dealing with medicinal ingredients, particularly Pliny's Historia naturalis and Dioscorides's De materia medica, which was again to be expected, given color's importance for the identification of medicinal ingredients and the overlap between the apothecaries' drugs and the simples of interest to naturalists.

Generally, Aldrovandi should be seen in the context of a growing minority of physicians and natural philosophers with a medical background, which included Girolamo Cardano, Théodore de Mayerne and Giulio Mancini, who became interested in colors and art collecting in the later sixteenth century. With its frequent recourse to medical sources, moreover, his commonplace book would seem to offer some concrete evidence in support of a recurrent claim among art historians about the connection between the diagnostic eye of the physician and the development of artistic connoisseurship. ${ }^{44}$

According to Aldrovandi's eighteenth-century biographer, MS 72 was an unfinished skeleton on which to base a richer discussion of the subject. ${ }^{45}$ Aldrovandi does describe it as a methodus, a capacious term that recurs in his Nachlass to describe his systematizations of areas of knowledge and natural particulars. Methodi were an established heuristic genre: a few

\footnotetext{
${ }^{41}$ The topics covered by Giovan Battista Montano, Aldrovandi's mentor, in his teaching of Avicenna's Canon included: "Whether color is an indication of temperature" and "The difference between colors"; in G.B. da Monte, In primam fen libri Canonis Avicenna explanatio (Venice, 1554), fols. 194r-211v. On the importance of color in the Hippocratic-Galenic corpus, see Laurence Villard, ed., Couleurs et vision dans l'Antiquité classique (Rouen, 2002), esp. the chapters by Villard, Boudon and Boehm.

${ }^{42}$ Laurence Moulinier-Brogi, L'uroscopie au Moyen Âge (Paris, 2012).

${ }^{43}$ Hilde-Marie Gross, "Illustrationen in medizinischen Sammelhandschriften. Eine Auswahl anhand von Kodizes der Überlieferungs- und Wirkungsgeschichte des 'Arzneibuchs' Ortolfs von Baierland,' in Ein teutsch puech machen: Untersuchungen zur landessprachlichen Vermittlung medizinischen Wissens, ed. Gundolf Keil (Wiesbaden, 1993), 172-348.

${ }^{44}$ Donatella Sparti, "Novità su Giulio Mancini: Medicina, arte e presunta connoisseurship,” Mitteilungen des Kunsthistorischen Institutes in Florenz, 52 (2008), 53-72, esp. 57-8; Alberto Frigo, "Can One Speak of Painting if One Cannot Hold a Brush? Giulio Mancini, Medicine and the Birth of the Connoisseur," Journal of the History of Ideas, 73 (2012), 417-36.

${ }^{45}$ Giovanni Fantuzzi, Memorie della vita di Ulisse Aldrovandi (Bologna, 1774), 141.
} 
pages of schematic notes that highlighted the links in a field of knowledge, usually via branching diagrams that worked by metodo divisivo (dividing larger categories into smaller units), and were meant to be used to draw up an account of the subject in question. ${ }^{46}$ The color table in MS 40 is a typical example of the genre (Fig. 4). Aldrovandi produced almost ninety of them with a variety of functions: from a basic outline for future works, such as the "Method to be used in Ulisse Aldrovandi's Treatise on plague"; to a schematic presentation of the outcome of a specific study, such as the "Method of the differences drawn from [the examination of] the internal and external parts of serpents"; to something closer to our color

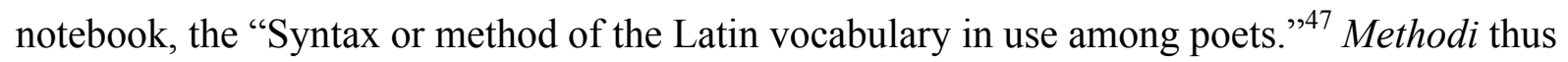
constituted both a practical methodology for further research and a pedagogical tool that helped in the exposition of knowledge-Aldrovandi allegedly found them useful in teaching his students the art of disputation. ${ }^{48}$ They were complemented in his Nachlass by over twenty lengthy syntaxeis. Even more ambitious, this sub-genre did not target individual issues, but aimed at taxonomizing entire fields of knowledge as Aldrovandi's "Syntax of plants" and "Syntax of animals" testify (Fig. 7). ${ }^{49}$ Both methodi and syntaxeis responded to the Renaissance encyclopedist's ambition of acquiring a universal knowledge of his subject while keeping an ever enlarging natural world under control. In this, they paralleled the act of reconstructing a microcosm of nature in the cabinet, where indeed synoptic tables were on display to help visitors apprehend the deep connections linking the specimens exhibited within. $^{50}$

If completed, this particular Methodus would not have offered a personal theory of optics, but a cultural atlas of colors in the manner in which Aldrovandi, and Conrad Gessner before him, envisaged the act of describing the natural world: by accumulating carefully all that was associated with one particular instance, denotations and connotations that would reconstruct that color's microcosm. Its strategy followed that of the largest and most

\footnotetext{
${ }^{46}$ Tugnoli-Pattaro, Metodo e sistema, 65-75. On the branching diagram's popularity among early modern writers, Blair, Too Much to Know, 144-52.

${ }^{47}$ BUB, Aldrovandi MS 54/I, 349r, "Methodus qua usurus est Ulysses Aldrovandus in tractatu de peste"; MS 66, 203r-207r,"Methodus differentiarum quae sumuntur a partibus internis et externis serpentium”; MS 74, 37-63, "Syntaxis seu methodus vocabolorum quae imposita sunt in lingua latina at quae sunt in consuetudine apud poetas."

${ }^{48}$ Tugnoli-Pattaro, Metodo e sistema, 74n14.

${ }^{49}$ BUB, Aldrovandi MS 80, fols. 1r-266r, fols. $272 \mathrm{r}-395 \mathrm{v}$, fols. $402 \mathrm{r}-445 \mathrm{v}$, respectively.

${ }^{50}$ Findlen, Possessing Nature, 60-1.
} 
ambitious encyclopedia produced by Aldrovandi, the Pandechion epistemonicon. Organized as an alphabetical dictionary of disparate subjects, its eighty-three volumes were conceived as a guide for anyone who wished "to know or write about whichever natural or artificial thing." $" 51$ There the reader would find everything "that poets, theologians, lawmakers, philosophers, and historians have written on the topic." 52 At a basic level, by compiling such a color lexicon Aldrovandi was working within a genre that restated his participation in a specifically erudite and classically-read scholarly community. Yet I believe this philologizing had a usefulness that went beyond textual exercise and should itself be seen as a color practice.

With MS 72, Aldrovandi was laying the first building-block in his architecture of a chromatic language that might serve his studies: by collecting and categorizing all that was known about color, the Methodus constructed an 'intellectual grammar' of color that his colleagues and students would have understood. Discussing the classicizing language used by fourteenth- and fifteenth-century Italian humanists to describe contemporary painters, Michael Baxandall has persuasively shown how, while seemingly detached from artistic production, this could provide a system of art criticism. Not only did humanists look in paintings for what they had become accustomed to in literature, such as considerations of composition or ordo, but they were guided (and constrained) in their understanding of what was aesthetically desirable by the semantic resonances and the syntactical qualities of the literary Latin they employed. ${ }^{53}$ Aldrovandi's commonplace book operates according to the same logic as a repository of such resonances. We can easily envision its author, confronted with a daub of 'black', immediately recalling the role Aristotle gave it in the generation of colors, then perhaps shifting to the image of Charon crossing the Styx or recalling its medical association with cholerics, and only then possibly pondering whether such pigment was obtained by crushing pieces of coal. An important testimony to the receptiveness of Aldrovandi's peers to such an intellectual grammar comes from a key figure in the Italian Republic of Letters and Aldrovandi’s correspondent, Gian Vincenzo Pinelli, who also

\footnotetext{
${ }^{51}$ Quoted in Tugnoli-Pattaro, Metodo e sistema, 19.

${ }^{52}$ Ibidem.

${ }^{53}$ Baxandall, Giotto and the Orators, 11-13; 49; 121-39.
} 
prepared a lengthy and equally unexplored Tractatus de coloribus, similar in approach if not necessarily in scope and intent. ${ }^{54}$

The second building-block in the creation of Aldrovandi's all-encompassing lexicon of color was the stabilization of the nomenclature. ${ }^{55}$ Here we turn to the companion notes in MS 40 and especially MS 95. The glossary in the latter records dozens of colors, most rendered with literary names and only timid incursions from contemporary painterly practice. Thus, terms shared with the artist's workshop such as ultramarine blue, Venetus blue, beretino and carmesino, sit next to the suggestive but less hue-specific arquatus (the color of the rainbow), guttatus (dappled), and xerampellinus (the color of dried roses). The scholar's interest throughout does not seem to lie in the materiality of pigment production and blending, but in the final effect, in the hue one could see on paper or canvas.

Looking more closely at this nomenclature, we notice that Aldrovandi draws heavily upon a handful of early sixteenth-century texts by Italian polymaths, which discuss GraecoLatin color nomenclature through examples from classical poetry and prose. Explicitly cited in MS 72, these include Antonio Telesio's Libellus de coloribus (Venice, 1528); Fulvio Pellegrino Morato's Del significato de' colori (Venice, 1535), notable for adding Christian scriptures, medieval Italian literature and lay proverb lore to the pool of classical sources; ${ }^{56}$ Ludovico Dolce's Dialogo delle qualità, diversità e proprietà dei colori (Venice, 1565), which took generously from the latter two named sources; and the widely reprinted Latin Dictionary (Bergamo, 1502) of Ambrogio Calepino from which all the above texts

\footnotetext{
${ }^{54}$ Milan, Biblioteca Ambrosiana, (henceforth BAM), MS D290 inf. Headed by an alphabetical index of colorrelated terms, this contains seven chapters covering the 'basic' colors (white, black, red, yellow, blue, green, varius) and their variations. Like MS 72, the notes have an antiquarian content and provide bibliographical references. Unlike MS 72, the sources are few and exclusively classical (primarily Pliny's Natural History and Gellius's Attic Nights), and the information is presented in narrative paragraphs headed by the relevant color term rather than by abstract categories. More attention is also devoted to the practical uses of pigments and colors among artists, doctors, goldsmiths, and dyers. Though no mention of either manuscript appears in the surviving correspondence between Aldrovandi and Pinelli, some exchange likely occurred. I thank Gabriella Zuccolin for her assistance in consulting this manuscript.

${ }^{55}$ Gessner referred to his Historia animalium and similar works with the term lexica. See Blair, Too Much to Know, 117.

${ }^{56}$ For Morato's sources, see Roy Osborne, On the Signification of Colours by Fulvio Pellegrino Morato (Boca Raton, 2013), 111-3.
} 
borrowed. ${ }^{57}$ Sharing a similar structure, whether in expository or dialogue form, these texts offered an antiquarian explanation of basic color terms and their linguistic and chromatic variations. ${ }^{58}$ At the same time, they spearheaded a novel genre of color etymology. ${ }^{59}$

While color had been an object of interest to medieval Latinate authors for its symbolic role in heraldic blazoning and Christian imagery, or as an expression of personality types in physiognomy, ${ }^{60}$ the novelty lay in the creation of glossaries that brought together Graeco-Latin color terms and discussed their lexical orgins. Prepared by grammarians and professors of rhetoric, the aim of these glossaries, as stated by Telesio, was to assist scholars in reading and composing Latin poetry and prose with renewed accuracy:

In this booklet, I shall say something about colours, yet not how they are manufactured, nor indeed what may be their nature, nor of what interests painters and philosophers, but [I will address] the philologists, who studiously seek after elegance in their Latin compositions. ${ }^{61}$

Consulted avidly by scholars throughout the early modern period, these works succeeded in giving new visibility to color as an object of study and new currency to ancient color terminology.

Taken at face value, the glossaries in MS 40 and MS 95 could be dismissed as Aldrovandi simply participating in yet another trend revived by the humanist investment in classical languages, that of lexicography. Undoubtedly, Aldrovandi was one of many scholars who tackled their study of the past by compiling dictionaries and wordlists, part of a more

\footnotetext{
${ }^{57}$ On the popularity of Calepino's dictionary, see Blair, Too Much to Know, 122-3. To these can be added Antonio Calli, Discorso de' colori (Padua, 1595).

${ }^{58}$ For an overview of the contents of Telesio's booklet, see Roy Osborne, “Telesio's Dictionary of Latin Color Terms", Color Research and Application, 27 (2002), 140-6.

${ }^{59}$ A precursor was Jean Lebègue's “Tabula de vocabulis sinonimis et equivocis colorum” (1431), as noted in Bianca Tosatti Soldano, "La 'Tabula de vocabulis sinonimis et equivocis colorum', MS Lat. 6741 della Bibliothèque Nationale di Parigi in relazione a Giovanni Alcherio,” Acme, 36 (1983), 129-87.

${ }^{60}$ See Gage, Colour and Culture, 80-90.

${ }^{61}$ Telesio, Libellus de coloribus, Prologue: "Dicam aliquid de Coloribus in hoc Libello, non quidem, unde conficiantur, aut quae sit eorum Natura, neque enim Pictoribus haec traduntur, aut Philosophis, sed tantum Philologis, qui Latini sermonis elegantiam studiose inquirunt.”
} 
general flourishing of reference works in early modern Europe. ${ }^{62}$ Yet, I contend that his concern for terminology was tightly bound with the role of color in the study of naturaliaitself a development owing to the new importance that the material culture of nature had acquired in the eyes of naturalists.

\section{Color Illustrated}

Both MS 72 De coloribus and related notes served a number of practical purposes for Aldrovandi. To understand these, we need to recall the latter's thoughts on 'art and science', which feature most prominently in five unpublished letters addressed to Paleotti between December 1580 and August 1581, as part of an ongoing conversation between the two on the role of the figurative arts in the devotional and intellectual life of humankind. ${ }^{63}$ An influential figure in the religious life of Bologna and involved in counterreformist debates about idolatry, Paleotti was primarily concerned about policing the boundaries between sacred and profane art. ${ }^{64}$ Aldrovandi's interest lay, instead, in what art had to offer to his natural historical activities. His was a concern typical of the sixteenth century, and a response to an intellectual reorientation in the use of material culture as evidence. Not only were physical specimens redefined as providers of information, but the archival artifacts produced to capture them visually (images) and physically (herbaria, cabinets) also became documentary sources. ${ }^{65}$ Such reorientation had roots both in the new interest which humanist culture fostered in antiquities and the material inheritance left by "the Ancients," 66 and in the new vogue for

\footnotetext{
${ }^{62}$ John Considine, Dictionaries in Early Modern Europe: Lexicography and the Making of Heritage (Cambridge, 2008), 7-17; 19-55; Blair, Too Much to Know, 117-32.

${ }^{63}$ Copies are in BUB, Aldrovandi MS 6/II, 97r-105v (6 Dec 1580); 108r-117r (5 Jan 1581); 119r-128v (20 Jan 1581); 129r-137r (21 Aug 1581); 138r-148r (undated) with a variant in MS 35/XXIV, "Minuta lettera al Cardinale Paleotti sopra il modo che tener debbono i pittori nel dipinger animali e piante," fols. 210r-217r.

${ }^{64}$ Giuseppe Olmi and Paolo Prodi, "Gabriele Paleotti, Ulisse Aldrovandi e la cultura a Bologna nel secondo Cinquecento," in Nell'età di Correggio e dei Carracci. Pittura in Emilia dei secoli XVI e XVII (Bologna, 1986), $213-35$.

${ }^{65}$ See Kusukawa, Picturing the Book of Nature; P. Findlen and P.H. Smith, Merchants \& Marvels: Commerce, Science, and Art in Early Modern Europe (London, 2002); Stephanie Moser, "Making Expert Knowledge
} through the Image: Connections between Antiquarian and Early Modern Scientific Ilustration,” Isis, 105 (2014), 58-99.

${ }^{66}$ Leonard Barkan, Unearthing the Past: Archaeology and Aesthetics in the Making of Renaissance Culture (New Haven, 1999); Paula Findlen, "Possessing the Past: The Material World of the Italian Renaissance," AHR, 103 (1998), 83-114. 
natural history, which itself experienced a transition in the early sixteenth century from a textual and philological rediscovery of nature to one reliant on its sensory appreciation. ${ }^{67}$

From Aldrovandi's writings emerges clearly the belief that to be epistemologically useful, 'art' must submit to 'science' (in practice to Aldrovandi's instructions), and that truthto-life should be the aesthetic principle governing the depiction of science's raw materials. Following a tradition of thought that harked back to antiquity, and referring specifically to Vitruvius, Aldrovandi believed that "painting should imitate things that are." ${ }^{\circ 8}$ Accordingly, he formulated the highest praise for a painter who was at the time in his service: "[his] figures truly appear like the simulacrum itself of nature, as they deceive the eyes of the beholders." 69 His letters to Paleotti supply specific indications: the artist must not leave anything to the imagination or give in to ornamentation. He should always strive to paint from life, with the specimen before him. His eye must be receptive to the changeability of nature: the variations that a plant displays through the seasons and its stages of growth, its different products, from resinous secretions to berries and seeds. Thus a plant in winter cannot be seen covered in leaves and flowers. Rather, separate drawings should be devoted to its separate stages of growth. ${ }^{70}$

Though historians have pointed out that these pictorial conventions were often breached, the accuracy and accountability they advocated underscored the point that images had to demonstrate and instruct before they delighted the beholder. This confronted naturalists with two immediate problems: whom to entrust with their illustrations, and how best to ensure that the end product answered their needs. Naturalists were bound, often to a disadvantage, to the existing art market and its modes of representation. The flora and fauna that traditionally supplied decorative elements in paintings had to be brought to the foreground and rendered in unprecedented detail. ${ }^{71}$ Aldrovandi regularly lamented the difficulty of finding reliable artists "in this genre," claiming that whilst every sort of painter could be found in Bologna, in his

\footnotetext{
${ }^{67}$ Brian V. Ogilvie, The Science of Describing: Natural History in Renaissance Europe (Chicago, 2006).

${ }^{68}$ BUB, Aldrovandi MS 35/XXIV, fol. 210r; also in MS 6/II, fol. 97v: “[...] si come testifica Vitruvio lib. 7 cap. 5 che la pittura debbe essere l'imitatione delle cose che sono."

${ }^{69}$ Aldrovandi, Discorso, fol. 557v: "[...] queste figure paiono propriamente il simolachro istesso di natura, che aggrabba gl'occhi de risguardanti."

${ }^{70}$ See n. 63 above, esp. 125r-126v, 138r-148r. Olmi, "Osservazione della natura," 105-18; Claudia Swan, "Ad Vivum, Naer Het Leven, from the Life: Defining a Mode of Representation,” Word and Image, 11 (1995), 35372.

${ }^{71}$ Giuseppe Olmi, Inventario del mondo. Catalogazione della natura e luoghi del sapere nella prima età moderna (Bologna, 1992), 119-61.
} 
life he had only found two who passed the test of scientific illustration. ${ }^{72}$ One was probably the Veronese miniaturist Jacopo Ligozzi, who contributed a handful of striking watercolors to his collection, including a drawing of two horned Libyan vipers received from the Grand Duke of Tuscany, which "are formed and depicted with such amazing artifice that they lack nothing but their spirit, so much are they made from the life" (Fig. 8) ${ }^{73}$. That artists, however, were more often casual hands is showcased by the apology presented to Aldrovandi by a correspondent, the apothecary Ippolito Geniforti, for his inability to send a drawing: his artist was busy applying a fresh coat of paint to the façade of his home. ${ }^{74}$

Aldrovandi tells us that the required level of accuracy can only be achieved after years of practice in painting flora and fauna. It is almost a process of re-education, whereby the painter is advised to go beyond his trade and acquire knowledge of both animate and inanimate things in order to "paint them correctly with their proper colors." If necessary, specialists should be consulted: "those who have knowledge of [naturalia], that he may know their figure either from drawings or descriptions, and so" - again — "give them their true colors." $" 75$ This also applies to the human form: he should "converse with anatomists and witness dissections first-hand [...] so that should he need to paint a martyrology [...] he may be able to do so." ${ }^{, 76}$ Aldrovandi seems to have been proactive in this training, intervening to guide the restraint and eye of his artists. Praising one of them, he recalled how "I kept him to practising continuously in these fine miniatures." 77 The knowledge of naturalia expected of the artist was a knowledge of visuals: surfaces, contours and colors; not of medicinal properties or nomenclature, which remained the province of the botanical expert. Yet there were more exchanges between the two groups than might at first appear. Notably, artists began to take advantage of the new museums for their own ends. Aldrovandi remembered:

\footnotetext{
${ }^{72}$ BUB, Aldrovandi MS 66, fol. 360v.

${ }^{73}$ Ibid., MS 6/II, fol. 111v: "[...] che altro non li manca, che lo spirito, tanto sono fatti dal naturale."

${ }^{74}$ Dario A. Franchini et al., La scienza a corte. Collezionismo eclettico, natura e immagine a Mantova fra Rinascimento e Manierismo (Rome, 1979), 30-4.

${ }^{75}$ BUB, Aldrovandi MS 35/XXIV, fols. 211r-v: “[...] quelli che n’hanno cognitione, accio possa sapere la loro figura o per delineatione o per scrittura dandoli i suoi propri colori.”

${ }^{76}$ Ibid., 216r. Similar statements had been circulating for a while and can be found, for example, in Girolamo Cardano's widely-read De subtilitate (Paris, 1550), fol. 266v: "pictorem omnia necesse est scire, quoniam omnia imitatur. Est philosophus pictor, architectus, et dissectionis artifex."

${ }^{77}$ Aldrovandi, Discorso, fol. 557v: “[...] havendolo io del continuo essercitato in queste miniature sottilissime."
} 
the late Lorenzino [Sabatini] and [Orazio] Samachini of Bologna most esteemed in their time who, whenever they needed to paint some plant or animal in one of their historie, came to me, and consulted [...] the thousands of pictures of natural objects made by my painter. ${ }^{78}$

Other names of artists external to his workshop are recorded in his museum's guestbook. ${ }^{79}$

Aldrovandi's insistence on the need to capture colors correctly must be understood in relation to a specific weakness of the medium of illustration, where most of the senses on which the naturalist usually relied to know nature found themselves muted. Taste, smell and touch, which in the field and the apothecary shop worked together with the faculty of sight, were useless before a paper specimen, leaving the scholar to depend exclusively on lines and colors. Given this constraint, one way to ensure a usable end result was to control the quality of the specimens the artist was given to copy. Thus, the plant should be fresh, "but an hour dug out from the earth, because dry plants cannot be painted" (it was common to wet dried specimens so that they recovered some volume and tint before drawing them). ${ }^{80}$ Animals also, particularly birds and fish, "must be procured alive or freshly dead." " Another method was to control the colors used to render the specimens, because "every substance we know thanks to this inseparable accident that is color." ${ }^{, 82}$ This is a statement that Aldrovandi takes from Aristotle's De anima and that recurs across his writings. Color is a nota beneficial to defining things, because "no thing could be seen if it weren't colored." Though a secondary characteristic, color is a "ladder and means, together with the other accidents, to achieve

\footnotetext{
${ }^{78}$ BUB, Aldrovandi MS 35/XXIV, fol. 211v: "Mi ricordo la buona memoria del Lorenzino et Samachino Bolognesi quali erano ne suoui tempi perfettissimi, secondo quando gli occorreva dipingere qualche pianta o animale in qualche loro historie, venivano da me, et pigliavano il trasonto et copia delle pitture che haveva fatto fare per mezzo del mio pittore."

${ }^{79}$ BUB, Aldrovandi, MS 136/XXIV, “Catalogus virorum illustrium ex variis diversisque nationibus, multorumque Bononiensium, qui visitarunt nostrum naturae oceanum," esp. fols. $21 \mathrm{v}-35 \mathrm{v}$.

${ }^{80}$ BUB, Aldrovandi MS 6/II, fol. 125v: "Di modo che voler dipingere le piante nauralmente [...] bisogna havere la pianta fresca e circa cavata all'hora dalla terra: perchè le piante essiccate non si ponno dipingere."

${ }^{81}$ BUB, Aldrovandi MS 136/VII, fol. 23r, "Catalogo delli ucelli che si trovano appresso M. Francesco il fillo del pittore del Granduca."

${ }^{82}$ BUB, Aldrovandi MS 6/II, fol. 109r: "[...] accidente inseparabile dalla sostanza, senza la cui notitia non si può venire alla cognitione di quel misto."
} 
perfect cognition of each species." 83 Several scholars have noted how indeed early modern naturalists could use color to disambiguate species, seasonal changes, stages of growth and in the case of animals also sexes (Fig. 9, Fig. 12). ${ }^{84}$ From Aldrovandi's perspective, therefore, mastering the subtle variation of hues-linguistically as much as visually, as we shall see below - would help not only to distinguish the age of a specimen, but also its kind.

For him, there was a clear hierarchy between lines and colors. Making a distinction between disegno (drawing) and pittura (painting), an act that had primarily to do with coloring, ${ }^{85}$ he saw in the latter the means of expressing the true impression of a specimen and readily ridiculed those who committed the blunder ("pigliati molti granchi") of coloring the plants engraved in Mattioli "with the same colour green." 86 Describing classification in Renaissance natural history as not "economical," in that it relied on the accumulation of characteristics that were not necessarily present in every species of a genus, Freedberg suggests that behind its lack of economy, in which color played an important part, lay the recognition of nature's mutability, which these sensory pickets were meant to contain. ${ }^{87}$ Aldrovandi clearly imagined color as a safety rope that kept the truth of nature connected to the necessary fiction of the image, an element around which he could construct the veracity of the representation. Almost paradoxically, should the artist lack in skill, color (if properly applied) would come to his aid.

\section{The Pitfalls of Language}

If color was one of the most immediate and safest clues for naturalists to follow, they needed to know how to define it and thus make their labors of identification communicable to their peers. Such need was only reinforced by the pedagogical activities of Aldrovandi, who had been teaching de simplicibus at Bologna since 1556 and therefore had to engage regularly in explanations of the notae of specimens. The artist's challenge of capturing properly the chromatic multiplicity of living things - the main cause of the difficulty of painting naturalia

\footnotetext{
${ }^{83}$ Ibid., fol. 109v: "[...] non si potendo vedere cosa alcuna, se non quanto è colorata"; "essendo scala et mezzo, insieme con gli altri accidenti, in conseguire cognitione perfetta di ciascuna specie.” On Aristotle, see Mark Bradley, Colour and Meaning in Ancient Rome (Cambridge, 2009), 63-4.

${ }^{84}$ Kusukawa, Picturing the Book of Nature, 63-79, esp. 106 on definitio ex accidentibus; Freedberg, "The Failure of Colour," 252; Ogilvie, Science of Describing, 135; 149-50; 205-7.

${ }^{85}$ BUB, Aldrovandi, MS 35/XXIV, fol. 210v. See also Thomas Da Costa Kauffman, Arcimboldo: Visual Jokes, Natural History and Still-Life Painting (Chicago, 2010), 118-21, 156-61.

${ }^{86}$ BUB, Aldrovandi, MS 6/II, 125r.

${ }^{87}$ Freedberg, "The Failure of Colour," 251-3.
} 
for Aldrovandi ${ }^{88}$ — was mirrored in the naturalist's quest for a terminology that might follow closely the subtle tonal variations the eye detected in nature:

Although plants are generally and for the most part of a green color, nonetheless there is an infinite variety among those greens, some being dark green leaning to black, others light [green] leaning to light blue, others to crimson, others to yellow, others to dark berretino [grey], others to the color tanedo [ochre]. ${ }^{89}$

Aldrovandi was pointing to an imbalance between perception and speech, to which his colleagues were similarly attuned. In the chapter on green in his own De coloribus, Gian Vincenzo Pinelli used the words of Gellius to highlight how the "discriminations of colors" perceived by the eyes remained unmatched by the paucity of the words in use. He reiterated, in the chapter on blue, that while "the appearance of colors are multiple [...], their appellations are uncertain and exiguous." ${ }^{90}$ Words were not only few, but also imprecise, blunt instruments.

A concrete example of how the complexity of translating color into words affected natural historical identification practices is found in a commentary by the Veronese physician Nicolò Marogna appended to the flora Monte Baldo descritto (1617) of Giovanni Pona. The latter was a renowned apothecary and correspondent of Aldrovandi. Discussing Indian amomum, a notoriously difficult specimen to identify, Marogna glosses Dioscorides'

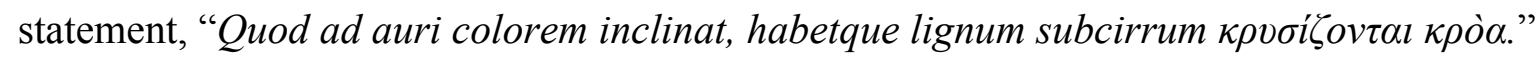
The first half is rendered as follows:

\footnotetext{
${ }^{88}$ Aldrovandi, Discorso, fols. 556v-557r.

${ }^{89}$ BUB, Aldrovandi MS 6/II, fols. 125r-v: "Et ancorchè le piante generalmente et per la maggior parte siano di color verde, nondimeno ci è una diversità infinita tra quei medesimi colori, essendo in alcuni verdi scuri, che tirano al nero, altri chiari che tirano all'azuro, altri al purpureo, altri gialleggiano, altri tirano al berretino, altri al color tanedo." This possibly elaborates on Telesio, Libellus de coloribus [15].

${ }^{90}$ BAM, MS D290 inf., 85r (from Gellius, Book 2, Ch. 26: "plurasque sunt in sensibus oculorum quam in verbis vocibusque, colorum discrimina simplices in viridis colores singula quidem vocabula, multas aut species differentes habent"; and fol. 77r: "Cum facies colorum multiplex sit appellationes aut incertae et exiguas").
} 
this does not mean that it has the same color as gold, but that it has something of the color of gold, or something similar to it. This color apparently lies between white and gold, which is called pallidus by Pliny and [pallidus] of second quality. ${ }^{91}$

This pallid tint characterised the Armenian variety of the plant, while the one from Pontus was closer to red. Employed to dispel confusion, the semantic tortuosity of this passage in fact betrays the difficulty of finding viable one-to-one descriptors. It is also a reminder that these lexical troubles were compounded by working with and across translations. As was the case with the struggles European botanists experienced with multilingual plant nomenclature, ${ }^{92}$ the vernacular was neither more helpful for fine-tuning nor necessarily transparent to the lay color practitioner. Thus Aldrovandi reflected: “Russus, color between sanguineous and red. I believe it is that color called Roggiado." 93

With their tracking of color variants, I would argue that both MS 40 and MS 95 testify to Aldrovandi's urge to navigate in and communicate these subtle variations. In addition to compiling as extensive a terminology as possible, in these writings he addressed the twin problems of vagueness and semiotic fixity that plagued color nomenclature. These could be phrased as follows: what kind of green is green? And, vice versa, how could one understand these shades once their name has been fixed on paper? His solution was twofold. Firstly, he sought to refine linguistically the distinctions between hues. He did so by attaching to several color names the prefix 'sub-', a modifier indicating a drop in intensity that enabled the observer to express small but often significant shifts in the appearance of naturalia. So we find subrussus, subcitrinus, subflavus, and even subpallidus and subcandidus incrementing the pool of classical terms. This morphological twist supplemented the traditional tools of the color lexicographers, who described tonal fluctuations by invoking spatial and hierarchical figurations through comparative syntactical structures (e.g., 'closer to', 'further from', 'redder than') and references to consanguinity that grouped individual hues in separate color subsets

\footnotetext{
${ }^{91}$ Nicolò Marogna, “Commentario nei trattati de Dioscoride e Plinio dell'amomo," in Monte Baldo descritto, G.

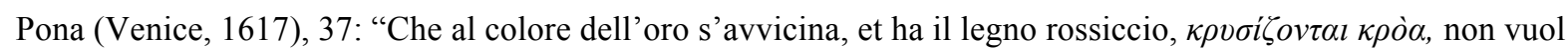
dire, che habbi lo stesso colore dell'oro, ma che ha del colore dell'oro, o che a quello s'assomigli, questo colore, pare che sia tra il bianco, et l'oro mezano, il quale da Plinio è pallido, er di seconda bontade chiamato."

${ }^{92}$ Ogilvie, Science of Describing, 173, 208-9

${ }^{93}$ BUB, Aldrovandi MS 95, fol. 359v: "37. Russus colore che è fra megio il sanguigno e il rosso, credo che sia quel colore che si chiama Roggiado.” .
} 
(such as purpureus congeneris and russus congeneris in MS 40). ${ }^{94}$ Aldrovandi almost certainly derived this practice from medical discourse and particularly uroscopy, where it was used to distinguish degrees of whiteness, yellowness, redness and blackness. ${ }^{95}$ The resulting fine distinctions charted a progression of darkness in the urine related to the level of coction of blood in the body (Fig. 10). In evidence by the twelfth century with a vocabulary of around twenty terms, this uroscopic palette seeped into most medical literature, and continued to circulate even when uroscopy itself lost prestige as a diagnostic practice in the later sixteenth century. ${ }^{96}$ Tellingly, Aldrovandi extended the usage of 'sub-' to the already rich lexicon of greens and blues (subglaucus, subcaerulaeus, subviridis), most useful to track not only the seasonality and age of plants, but also the kaleidoscopic plumage and scales of birds and fish - the two main animal taxa he studied.

If of dubious effectiveness in practice, this semantic multiplication displayed an intriguing synergy with the sustained attempts of contemporary painters at replicating luster, shine and tonal variation on canvas by experimenting with new materials. Driven by similar concerns with mimesis, sixteenth-century artists strove to reproduce the effects that light had on the appearance of objects with new smalts and glassy pigments obtained by crushing luminous glass, marble and metals. ${ }^{97}$

For Aldrovandi the problem with the 'old materials', namely the color nomenclature inherited from Graeco-Latin literature, was the gap between the uses envisaged for it by 'the Ancients', and the uses demanded of it by Renaissance naturalists. This was, for the naturalist, the difference between a primarily poetic and oratorical language, conceived to

\footnotetext{
${ }^{94}$ Marogna's phrasing on the abovementioned amomum's subcirrum color is typical: “certain wise men observe that yellow, blond, red, tanedo or lionato [tawny] are consanguineous and almost bound by kinship, and that they do not differ from each other but for one being more or less intense than the other," as found in Pona, Monte Baldo descritto (1617), 37. See also the aforementioned lexicographers and Cardano, De subtilitate, fols. 266v-267v; Scaliger, Exotericarum exercitationum liber $X V$., fols. 434v-444r.

${ }^{95}$ Moulinier-Brogi, L'uroscopie au Moyen Âge, 151.

${ }^{96}$ Michael Stolberg, "The Decline of Uroscopy in Early Modern Learned Medicine,” Early Science and Medicine, 12 (2007), 313-36. There is evidence that Aldrovandi was not the only one to bring the two traditions, literary and medical, together. Telesio's De coloribus was regularly bound and sold together with tracts on uroscopy. E.g., see following editions of Johannes Zacharias, De urinis Actuarii [...] libri VII (Paris, 1522, 1548, 1670; Basel, 1529, 1543).

${ }^{97}$ See Barbara H. Berrie and Louisa C. Matthew, "New Materials on the Renaissance Artists' Palette," in Materials Issues in Art and Archaeology VII, vol. 852, eds. Jennifer Mass, John Merkel, Alison Murray, and Pamela B. Vandiver (Boston, 2005), 852: 131-40; and Berrie in this volume.
} 
embellish literary tropes, render abstractions and evoke powerful emotional responses, and a language meant to record accurately the appearance of the natural world. While providing a general reference as to where a name might fall on the chromatic spectrum, standard associations in the inherited literature — such as that between the term cymatilis and "the color of the sea," or rather a putative sea once beheld by Plautus; or between arquatus and "the color of a rainbow" radiating from the verses of Catullus; or caesius and the refulgent eyes of the pagan goddess Minerva and of dangerous beasts like panthers and lions-were of limited help in the study of particulars. ${ }^{98}$ As Telesio had already observed, besides, classical authors were not shy of substituting one term for another for better poetic fit (albus for pallidus for instance), further undermining their similes' usefulness to those concerned with mimesis. ${ }^{99}$

Several classicists, moreover, have recently argued that color terms in antiquity were more qualitative and less connected to a specific hue than we are accustomed to today: for instance caeruleus, usually associated with the sea, was not meant to suggest a 'blue' surface so much as one possessing a quality akin to the sea itself, deep and agitated. Similarly, viridis did not simply stand for greenness and for the metaphorical connotation of 'yet to grow' and hence immature that it carries to this day, but also for the state itself of 'vigor' and 'growing'. ${ }^{100}$ In this language of color perception, synaesthetic suggestions, which activated senses other than sight, were never far from the word's surface, and primary and secondary connotations could disagree, leading to seemingly odd juxtapositions such as flavus rubor or 'flaxen blush', in reference to the blond hair framing a youth's cheeks. ${ }^{101}$ This gave a vibratility, a quivering, mobile quality to words and their meanings that would have complicated any Renaissance reading of ancient color nomenclature.

It is difficult to measure the extent to which such a layered approach to color was 'thinned out' across the centuries; and whether early modern naturalists sought to discard or simply failed to capture these inherent associations, thus 'flattening' the experience of color terminology into that of univocal visual-linguistic correspondences. When, for example, did caeruleus lose its nature of 'color of the sea' and become turquoise? Aldrovandi seems to be after such univocity, as his glossary strives to link each term with a specific hue that may be

\footnotetext{
${ }^{98}$ Telesio, Libellus de coloribus, [21]; Ludovico Dolce, Dialogo delle qualità, diversità e proprietà dei colori (Venice, 1565), 13.

${ }^{99}$ Telesio, Libellus de coloribus, [17].

${ }^{100}$ Bradley, Colour and Meaning in Ancient Rome, 1-12.

${ }^{101}$ Mark Bradley, "Colour as Synaesthetic Experience in Antiquity,” in Synaesthesia and the Ancient Senses, eds. Shane Butler and Alex Purvis (Cambridge, 2013), 127-40.
} 
found in qualitatively different objects. To produce accountable descriptions of naturalia, the terms need to be replicable and not slippery in their meaning. In doing so, however, the naturalist turns hue into the dominant element of the discussion, and makes of Graeco-Latin color terms abstractions that originally they had not been. ${ }^{102}$

Perhaps not surprisingly, therefore, Aldrovandi's second solution in his quest to create a viable chromatic lexicon for natural history, was to tackle the link between term and referent in order to disambiguate the meaning of color terms. He did so by replacing the similes inherited from antiquity with new ones. ${ }^{103}$ Implicit in the work of lexicographers such as Telesio and Morato, an abstract discussion of the bond between res and verba figured prominently in two authors repeatedly cited by Aldrovandi, Cardanus and Scaliger. Their concern was primarily for etymology, for understanding how a color term had arrived at its linguistic form, but their analysis provided a useful model as well as concrete analogies that Aldrovandi could borrow to describe color variation. Scaliger especially elaborated the notion that most color terms implicitly contain a simile with an originary object, either "the first one in which the color can be seen or the first one in which it is expressed excellently"-igneus from fire would be an example of the former, and roseus from rose or sanguineus from blood of the latter. Color names could thus be traced back to the elements, metals, gemstones, plants and their "excrements," animals and regions. ${ }^{104}$ Reconstructing this genealogy was important because names were believed to embody the essence of things, and therefore, Scaliger explained, were not only useful in conversation but for understanding the very nature of what

\footnotetext{
${ }^{102}$ Ibid., 130-1.

${ }^{103}$ Standard tools of poets and rhetoricians, figurative language and similes to familiar objects had been employed since antiquity also in herbal literature to produce viable descriptions of natural specimens. See Leah Knight, Of Books and Botany in Early Modern England: Sixteenth-Century Plants and Print Culture (Aldershot, 2009), 92-8.

${ }^{104}$ Scaliger, Exotericarum exercitationum liber $X V$., fols. $437 \mathrm{v}-438 \mathrm{r}$ : "Quae colorum nomina, et unde. Colorum nomina quorundam ostendunt essentiam, et quasi pro differentia sumi possunt ad speciem describendam. [...] Exempli gratia: Sanguineus est, qui sanguinem repraesentat. Qualis in rosa. [...] Non solum igitur utilia sunt ad disquisitionem: verum etiam ad cognitionem necessaria [...] Aliis certus ortus est. Quorum quaedam a Graeco transumpta sunt $[\ldots]$ Ab elementis [...] A metallis, lapidibus, gemmis, terris [...] A plantis, et plantarum partibus, ut foliis [...] A plantarum excrementis [...] Ab animalium partibus [...] A regionibus.”
} 
they described. ${ }^{105}$ More modestly, Cardano believed that the best method to learn color terms was by associating them with memorable things. ${ }^{106}$

Going back to MS 95's glossary, we notice that the similes employed make exclusive reference to naturalia, excising any mention of literary and social contexts and indeed of all auctoritates. Associations to natural objects featured already in classical texts: a faithful chronicler, Telesio for example linked pullus to "the back of a hare," and viridis to "the plumage of parrots." 107 Some pairings went as far back as the Hippocratic corpus, where symptoms were likened to everyday objects such as milk, wheat and lentils, and where references to comparable colored objects were probably meant to evoke also a kind of texture and smell for the body part to which they were applied. ${ }^{108}$ Some associations probably came from Scaliger's etymological analysis, such as "Palearis, like straw" and "Spiceus, the color of wheat." 109 Others, such as "Lividus like bruises," arguably derived from the vocabulary of medieval uroscopy where, as Moulinier-Brogi notes, there had already been an effort to adapt unworkable similes referencing Near Eastern exotica to the authors' continental European reality. ${ }^{110}$

Yet, many similes are the product of Aldrovandi's own fieldwork. Flowers and roots in particular are seen as stable referents, producing pairs such as "Subalbidus, whitish like the root of Acorus," "Flavus like the linden flower," "Cloron, light green like oranges beginning to mature and the bird called verduro or verdone," "Buxeus imitates liquorice root," "Beretino, like the leaf of chicory," and "Purpureus, like the flower of the common hazelwort and gladiolus, the bird porphyrio and some species of wrasse." "111 A comparison may be made between this 'naming from life' and the painting from life that Aldrovandi asked of his artists.

\footnotetext{
${ }^{105}$ Ibid. For how these thoughts fit in the medieval and Renaissance etymological tradition, see Marian Rothstein, "Etymology, Genealogy and the Immutability of Origins," Renaissance Quarterly, 43 (1990), 33247.

${ }^{106}$ Cardano, De subtilitate, fol. 266v.

${ }^{107}$ Telesio, Libellus de coloribus, fol. 6v; fols. 10r-v.

${ }^{108}$ Bradley, Colour and Meaning in Ancient Rome, 130-5; Bradley, "Colour as Synaesthetic Experience in Antiquity," 133; Villard, Couleurs et vision, 45-64.

${ }^{109}$ See Scaliger, Exotericarum exercitationum liber $X V ., 439 \mathrm{r}-\mathrm{v}$.

${ }^{110}$ Moulinier-Brogi, L'uroscopie au Moyen Âge, 152. Some associations were nonetheless persistent. Ulrich Pinder's early sixteenth-century urine wheel still explained caropos (bluish-grey) by reference to a camel's coat (“ut vellus Cameli”) (see Fig. 6).

${ }^{111}$ BUB, Aldrovandi MS 95, fols. 359r-360v; MS 40, fols. 118r-121r.
} 
By playing with language Aldrovandi was reactivating the textual tradition for his needs. Yet it was not just about rendering the past relevant to the present in the manner of his humanist predecessors. The epistemological action was more subtle and resembled that which Paula Findlen has documented for another momentous development of the late medieval period: when the musaeum, the realm of the muses, was taken out of its textual environment and transformed from a metaphor recurring in classical and neo-classical literature into an actual repository. ${ }^{112}$ Like the philologizing of MS 72, Aldrovandi's recourse to personal experience and the emphasis on natural similes meant absorbing the basics of an extraneous craft (that of the painter) into the familiar scheme of knowledge of his own discipline. But it also provided a useful frame of reference for his own activity as a patron, creating a common ground for the naturalist to articulate his demands. After all, scientific illustrations were boundary objects between color worlds-the naturalist's and the artist's.

Aldrovandi was experimenting with a language to talk across domains. According to Olmi, he supervised his artists' manufacture of pigments. ${ }^{113}$ He certainly could consult his list before instructing his painter on a color choice_-particularly when the sketching was not from life but, as was common, from third-party drawings or dry specimens, and thus the naturalist's expertise would have been a necessary corrective. As such the words and similes of his glossaries should be considered not just descriptive, but also performative. Whether he could go one step further and ask his artist to 'paint in the shade that resembles straw', in a prosaic reversal of the principle underpinning the relationship between images and writing in the early modern period, ut pictura poesis, ${ }^{114}$ remains to be proven. Though it is important to note that many of the natural objects used as referents - think of chicory and hares - were everyday sights shared by patron and artist. ${ }^{115}$ Be that as it may, creating a dictionary of colors that covered a sufficient number of variations was crucial, and I believe we should look

\footnotetext{
${ }^{112}$ Paula Findlen, “The Museum: Its Classical Etymology and Renaissance Genealogy,” Journal of the History of Collections 1 (1989), 59-78.

${ }^{113}$ Olmi, "Osservazione della natura," 112-8.

${ }^{114}$ Rensselaer W. Lee, "Ut pictura poesis: The Humanistic Theory of Painting,” The Art Bulletin, 22 (1940), $196-269$.

${ }^{115}$ Others gave up on verbalizing, turning to the material language of the artists' pigments. After repeatedly confessing his inability to render in writing "the sundrie mixtures of colours that nature hath bestowed" on plants and flowers, the English naturalist John Gerrard changed tack: "to describe the colour in words, it is not possible, but this waie; laie upon paper with a pensill a yellowe colour called Masticke, which being drie, laie the same over with a little saffron steeped in water or wine, which setteth foorth most lively the colour" (quoted in Knight, Of Books and Botany, 98).
} 
at Aldrovandi's color writings as a measure of his intervention in the artistic process, something he very much viewed as a collaborative practice.

But there is an additional dimension. This scientific production did not occur in a vacuum. As members of the professional, retail and merchant classes, naturalists participated in the growing Renaissance consumerism, purchasing paintings, prints and small sculptures in bronze or plaster, and using them to decorate their domestic interiors. As Renata Ago has shown, images of the Virgin and the saints were staple purchases, followed by more expensive historie narrating mythical and political events, and by the occasional landscape and still life. ${ }^{116}$ This consumption was certainly one source for the naturalist's sensitivity to color and skill. Aldrovandi, for example, commissioned a portrait from Bartolomeo Passerotti (Bologna, 1529-1592), known for his realistic market stall scenes (Fig. 11). ${ }^{117}$

The clearest case of dialogue between art market and science, however, features in the work Aldrovandi funded in his country villa in Sant'Antonio di Savena in the 1580s and 1590 s, unfortunately demolished in the nineteenth century. Beside a portrait gallery featuring notable personages after the example of Paolo Giovio, and a gallery of emblems that used animals and plants as allegorical figures, the villa boasted a fresco series illustrating the life and virtues of the Homeric Ulysses and, with Ulysses as a reference, of Ulisse Aldrovandi himself. ${ }^{118}$ The naturalist designed the project himself, deciding which parts of the myth would be illustrated, how they should be broken down into separate sections, which characters would feature and in what number. He left several drafts with avvertimenti that trace this gradual process of composition and read as reminders to himself and instructions to the painter. ${ }^{119}$ It is interesting to see how, on the one hand, Aldrovandi makes allusions to values typical of the art market: telling us proudly that the series required 132 human figures, aware that this number customarily determined the price tag of an artwork. ${ }^{120}$ On the other

\footnotetext{
${ }^{116}$ Renata Ago, Il gusto delle cose: una storia degli oggetti nella Roma del Seicento (Rome, 2006).

${ }^{117}$ Alessandro Tosi, "Il ritratto della scienza," in La ragione e il metodo. Immagini della scienza nell'arte italiana dal XVI al XIX secolo, eds. M. Bona Castellotti, E. Gamba, and F. Mazzocca (Milan, 1999), 17-32. 118 Through this traditional exercise in etymology, Aldrovandi was also responding to a wider artistic trend of sixteenth-century Italy, where the myth of Ulisses had become a privileged thematic source for fresco series (Marco Lorandi, Il mito di Ulisse nella pittura a fresco del Cinquecento Italiano (Milan, 1995), 13-67).

${ }^{119}$ Lina Bolzoni, "Parole e immagini per il ritratto di un nuovo Ulisse: L' 'invenzione' dell'Aldrovandi per la sua villa di campagna," in Documentary Culture: Florence and Rome from Grand Duke Ferdinand I to Pope Alexander VI, eds. E. Cropper, G. Perini and F. Solinas (Florence, 1991), 317-48.

${ }^{120}$ Jo Kirby, “The Price of Quality: Factors Influencing the Cost of Pigments During the Renaissance," in Revaluing Renaissance Art, eds. Gabriele Neher and Rupert Shepherd (Aldershot, 2000), 19-41.
} 
hand, his natural historical passion resurfaces when scripting the scenes. Commenting on the fifth quadro, which saw Ulysses driven by the winds to Libya and the Lotus Eaters, he glosses:

The lotus tree is large and similar to the pear tree, its fruits as big as favas and numerous. The tree trunk should be large, the branches dense and reaching outward like those of the mulberry, the leaves incised. The fruits should be red with a little dry yellow. The mainland, being Africa, could be shown separated from the [Lotophagi] island by the sea, and with a lion, because Africa engenders lions. ${ }^{121}$

This project raises a number of questions, including that of artistic connoisseurship. These were years of a growing debate in art theory about who had the authority to judge the quality of paintings, the painter who made them or the art lover who bought them. In 1619-20 another physician, Giulio Mancini, would publish his influential Considerazioni sulla pittura, supporting the case of the non-painter connoisseur. Notably, Mancini identified color, alongside perspective and the expression of affect, as elements of painterly expression that a layman could learn to discern after training his judgment by viewing many paintings and listening to the experts. ${ }^{122}$ It is not clear to what extent Aldrovandi would have agreed: despite his lavish spending, he remained cautious towards the wider art market. Asked by a Ferrarese gentleman to "turn Bologna upside down" to obtain thirty drawings from the Carracci brothers, he explained that, not being acquainted with them, he had sent a painter, "my friend." 123 Apparently the Carracci had no desire to produce said drawings, yet informed their potential customer of their cost: five to six gold ducats each, with an advance of thirty ducats. Observing that "truthfully these have a very high opinion of their own art, because they are

\footnotetext{
121 “Avvertimenti. I loti erano arbori di molta grandezza et quasi come un pero, i frutti grandi come una faba et di questi frutti ve n'era una selva [...]. I tronchi de l'arbori siano grossi, i rami espansi come i rami del moro, le foglie incise. Siano rossi i frutti, con un pocco di giall seco [...]. Potriassi far apparire terra ferma che seria l'Africa divisa da l'Isola con un braccio di mare, et porvi un leone, essendo che l'Africa partorisce i leoni." BUB, Aldrovandi MS 97, 593v-606v, "Effigie et habito di Ulisse. Discorso sopra le pitture di Ulisse che sono nel suo palazzo nel Comune di S. Polo," fol. 598r.

${ }^{122}$ Sparti, "Novità su Giulio Mancini," 59.

${ }^{123}$ BUB, Aldrovandi Ms. 21/IV, 89r-90v, "Lettera al Cav. del Cornetto, Gentiluomo di Camera del Duca di Ferrara" (25 Apr 1595), fols. 90r-v: "[...] per dirli il vero costoro tengono l'arte sua molt'in alto per essere de primi pittori e hoggidì si partono et sono chiamati a Roma [...] bisognerebbe che fossero negociati da persona dell'arte, acciò potesse far giudicio del valore delle pitture, havendo il pagare tanta gran soma di denari."
} 
among the first painters," Aldrovandi advised the gentleman to have the drawings assessed by a "persona dell'arte" (an art dealer), so "that he may judge the value of these pictures, given that so much money is being asked." ${ }^{124}$ Conversely, the potential conflict that seems to be at issue here, between the judgment of an expert and that of a lay connoisseur-consumer, was simply not applicable to the case of scientific illustrations. There, the rights to connoisseurship can be claimed because there is no conflict: art is led by science. The naturalist defines the parameters for the picture, and a specialist audience confirms its veracity and use.

\section{Conclusion}

This context further illuminates the utilitarian undercurrent of Aldrovandi's writings on color and of a philologizing practice seemingly detached from considerations of workshop practice. His writings served as a trait d'union between different spheres of patronage and knowledge production. Color lists and diagrams, which mastered the chromatic scale and built a vocabulary of color variations that made sense to him, enabled Aldrovandi to articulate fruitfully the passage from verbal (his stock-in-trade) to visual, and control his workshop's production, be it for scientific drawings or celebratory canvasses. Conversely, with MS 72 Aldrovandi imagines a cultural lexicon that would grant him prestige among his peers, and concurrently provide a manual for himself. The notebook can be seen as a heuristic tool to cultivate his connoisseurship: its collection of facts and definitions helped to acquaint oneself with color symbolism and connotations that would have made the naturalist sufficiently competent to decode meanings in contemporary artwork, and an authoritative judge of which hues to use in the artwork he commissioned. In doing so, Aldrovandi was performing an act of translation, rendering the practice and discussion of colors and art into his own language. This had a composite grammar that took its rules of composition on one side from the language of close examination and description of naturalia, and on the other from the language of philology and the activation of the textual heritage of ancients and moderns. It was a composite language which most of Aldrovandi's peers, for whom a university education intersected with an interest in nature, would have had no trouble becoming literate in. This should be taken with the caveat that this was an operative language that made sense to a humanist and was nurtured by a tradition invested in the power of the word and writing.

\footnotetext{
124 Ibid.
} 
How best to communicate issues of color to fellow naturalists did not necessarily equate to best practice when dealing with artists.

FIGURE 1. Ulisse Aldrovandi (1522-1605) in a portrait executed in 1574 by one of his artists in residence, the Florentine Lorenzo Benini, and then reused for one of the two major works Aldrovandi published in his lifetime, the Ornithologia hoc est de avibus historiae libri XII (Bologna, 1599), frontispiece. Public domain.

FIGURE 2. BUB, Aldrovandi, MS 72, Trattato dei colori, c. 49r. The pages are written on the recto side only, partly in Aldrovandi's hand and partly in one of his scribes'. Courtesy of the Bologna University Library.

FIGURE 3. BUB, Aldrovandi MS 95, c. 359r. Courtesy of the Bologna University Library.

FIGURE 4. BUB, Aldrovandi, MS 40, c. 119r. Following loosely the Aristotelian seven-colour scale, the diagram organizes the main colours and their variations as follows: E. Nigro congeneris (16 variants), D. Purpureo colori congeneris (19 variants), C. Rubeus congeneris (26 variants), B. Viridis congeneris (9 variants), A. Ceruleo (6 variants), 1. Albus. Courtesy of the Bologna University Library.

FIGURE 5. BUB, Aldrovandi MS 95 , c. 361 r. The broadsheet offers a view of Caffa surmounted on the left by three suns enclosed by two half circles, and on the right by a cross above a half moon. Aldrovandi probably picked this specific print on wonders among the many that filled the bookshops and bags of pedlars, because of the rainbow enclosing the three suns, which he proceeded to colour in in white, red, green/yellow, violet following closely Aristotle's Metereologica, where the colours of the rainbow are described as being red, green, violet. Courtesy of the Bologna University Library.

FIGURE 6. Urine wheel from Ulrich Pinder, Epiphaniae medicorum (Nurenberg, 1506), f. Aiv. Coloured in by hand. Although the majority of these tables are likely to have remained uncoloured, they represented one of the very few 'colour swatches' circulating outside the specialist domain of art and textile trades. Courtesy of the Wellcome Library.

FIGURE 7. Ulisse Aldrovandi, 'Syntaxis de Insectis', in BUB, Aldrovandi MS 80, cc. 402r-445v, 402v. Courtesy of the Bologna University Library.

FIGURE 8. A gift from the Grand Duke of Tuscany to Aldrovandi, these Libyan vipers were painted from life by Jacopo Ligozzi (1547-1627). BUB, Aldrovandi, Tavole Vol 004 Animali, c. 132r. Courtesy of the Bologna University Library.

FIGURE 9. BUB, Aldrovandi, Tavole Vol 002 Animali, c. 16r. 'Psittacus viridis, rostro partim luteo nigro alarum costa rubescente'. Courtesy of the Bologna University Library.

FIGURE 10. Ulrich Pinder, Epiphaniae medicorum (Nurenberg, 1506), f. Aii. Courtesy of the Wellcome Library.

FIGURE 11. Bartolomeo Passerotti, Portrait of Ulisse Aldrovandi, $19^{\text {th }}$-century copy by Pelagio Pelagi. Oil on canvas, $79 \times 62 \mathrm{~cm}$. The portrait itself reflected a new vogue in nothern Italy and Europe for portraits of 'scientists': mathematicians, astronomers, physicians surrounded by the instruments of their skill. Naturalists joined in from the second half of the sixteenth century, posing with tell-tale books and flowers. Public domain.

FIGURE 12. BUB, Aldrovandi, Tavole 009 Piante Fiori frutti c. 344r. 'Cicer arietinum rubeum maius'. Courtesy of the Bologna University Library. 
"Mnatio. Coloris Vwidis utros sumb uary" Colores. Tartar.m physifnst. fon 3 . F. log.

Colov urins quid. Color m wrinis al bumoribuy prouenit. Jo. frant de llem. 270 .

Species eum fynomimis. Color rutus birrus etzan diritur Barron. tom.2 Aimal. sq1.

Twith colorum. Tritor Colorw fuic En gomes pitor. vulye marinatov bi colov. plin. 35 . et 11 .

Species. Oolor nitia uiride et corwlan intitur glaurimus Calepm.

Species cum fynomimis: Colov turami nus duritur a tur quina gemma, color 1 .
ceruleus

Hlystice. Colov nirides un nivtucti

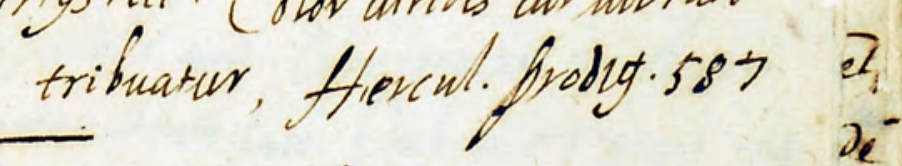

Species. Rose Coloven imitans ductur vosens, gurabmodn pamnes Lesaus, et vistis rosea.

Species. Color Castaneus est the gai milgo

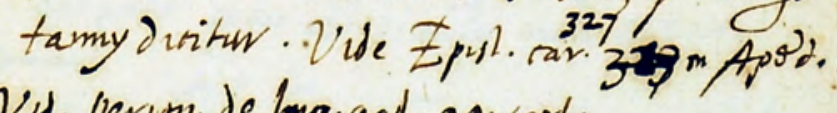

1 Vw. perion de img.gal. 99 carl.

Causesa. Coloris caussas declarat Hotanus

inarte parua gall pr

Timifa: mark par. hib.2 fen. $34 \cdot$ is 


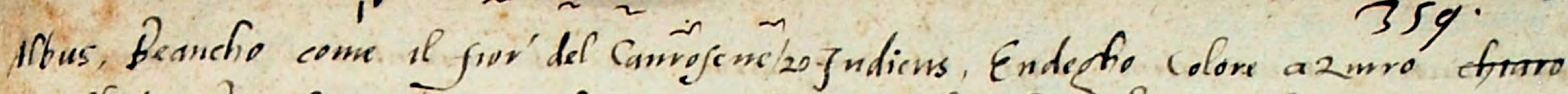

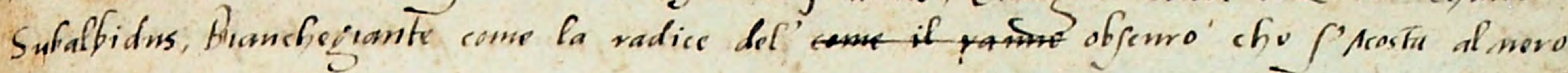
Acoro Aggentinus Glere d' Argento

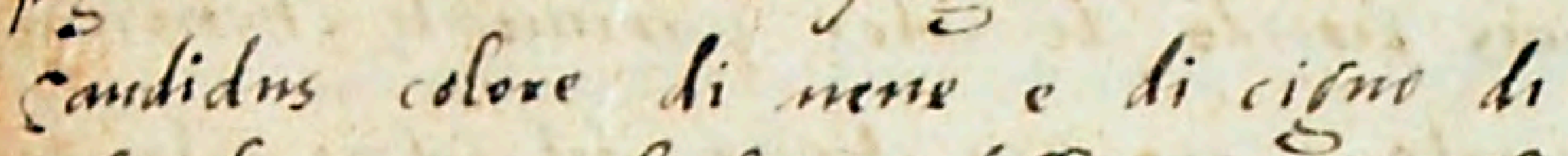
Columba come if fiore detTa prafsinetla Subcaididus aignanto cantido "C iolacens color di crofa digmavesinen oner di narzo

ar viridis, crmme nille perme di papapallo et comme do Smiraldo

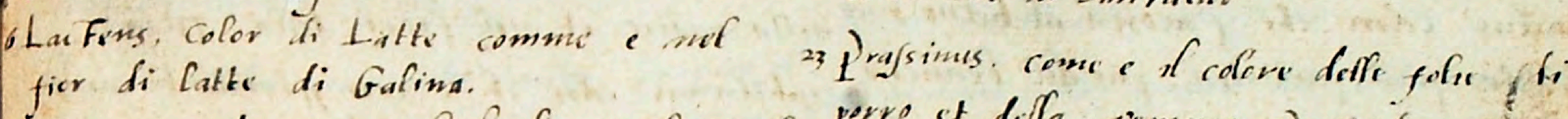

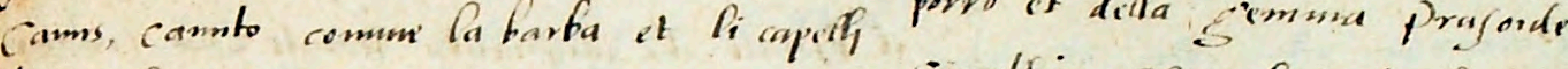
le vech.

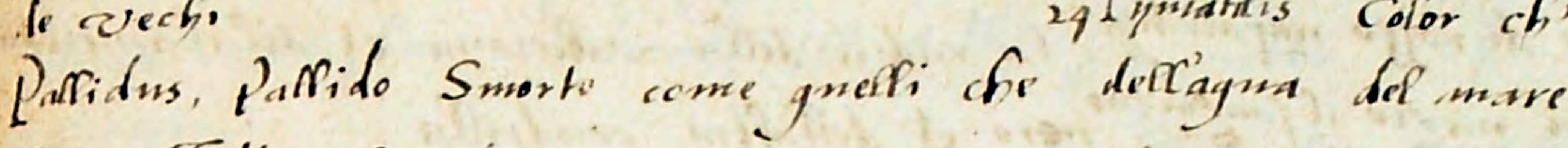

sone sfati infermi

'Sufrarlidus, Smortaiolo smartiRRe prigmanto palito omer yallideto. Jums ofor li forno di bussolo ifo imita fa radice deresolita Liwidus colore jopramodo palfido paflidisfomo

Pinerens, cineritio color di cousere Beretivo come s la folin del vedichelio Ex alfo pallidus di color Biandfice cheg' Aasti al Smorte

Punicens color del fion dit parauero

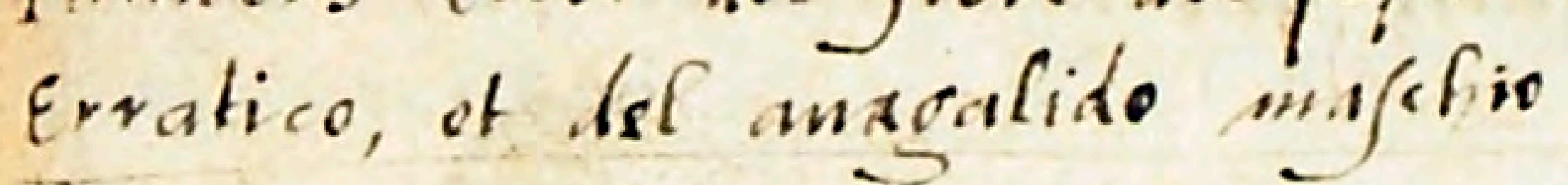

\section{3}

Cerulous coler azmro oner colosfo comedel ochie li iatla

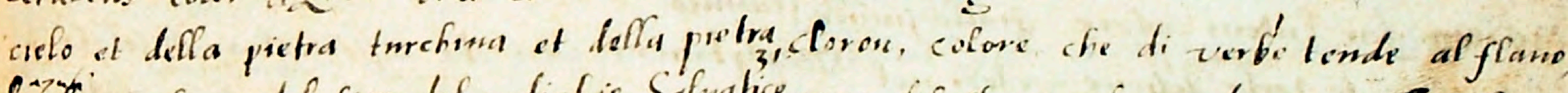

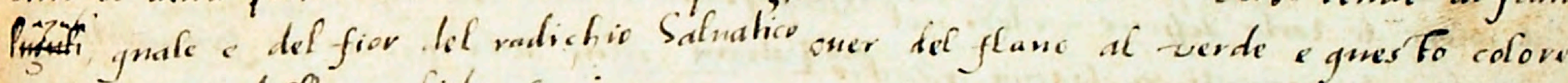
et gatino et deflanaralide formina

Snlecenlens Af quanto Azuno unpocho

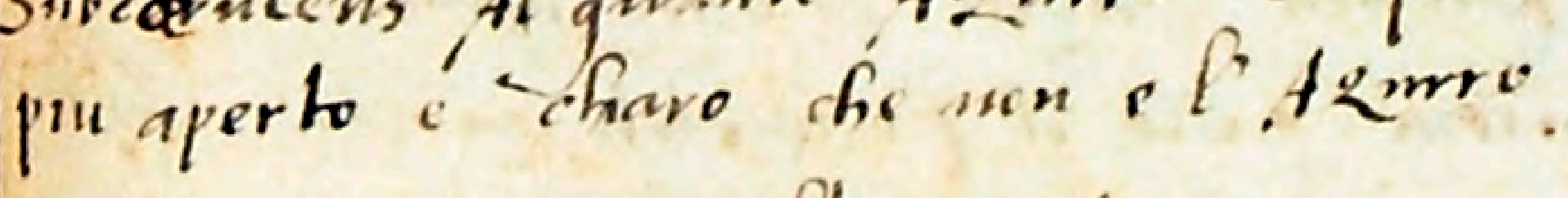

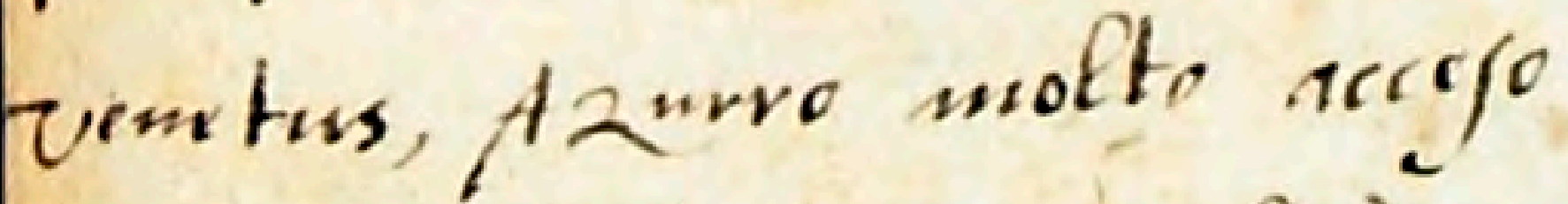

Inoro oftramariono, correfins indicus

Argentino colore Azenre diono senmu it pamso Argentine azzure.

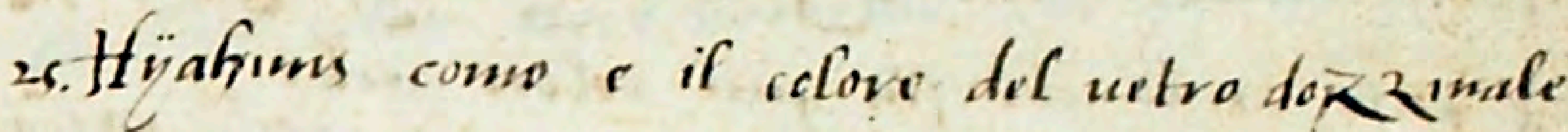
26. Batrachion cofor verdigiante conce if vanechio

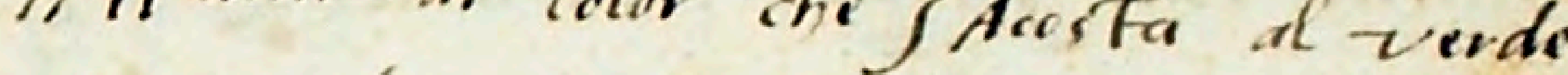
sservinidi fraugeons coler verde che faproxinsa al pano fo comefi uede in $y^{\text {me }}$

2a) Cofius Cofore fimite af' ocfies di gatta

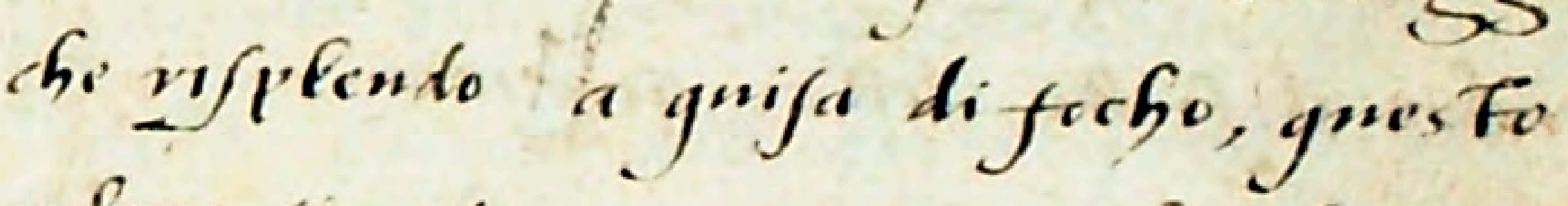
colove fi retromi ausera nel jafai 3o Sulfolaucus colove the fi Acorfa al cegio

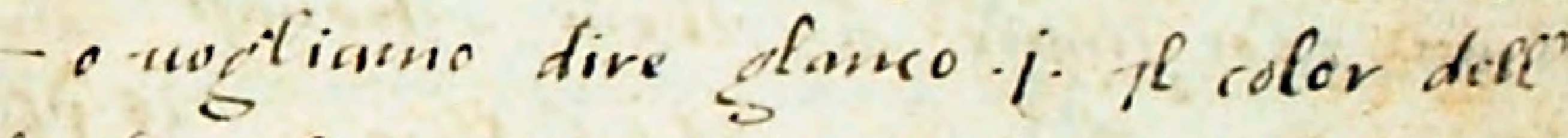
pinute

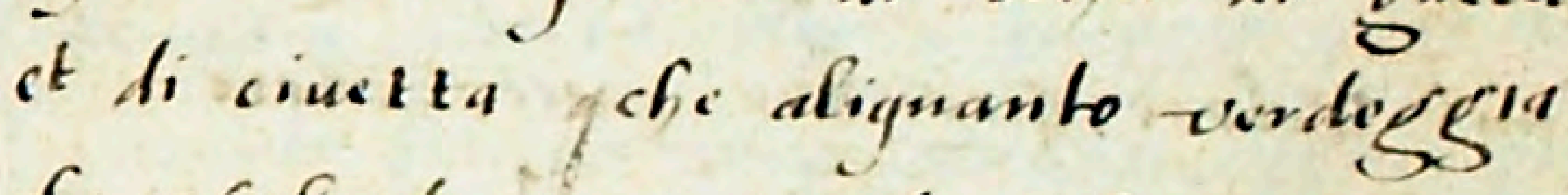




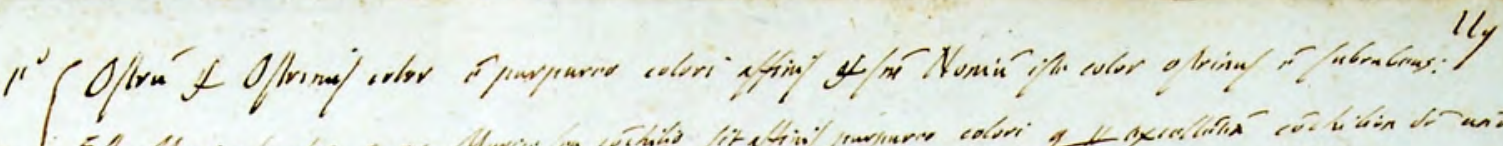

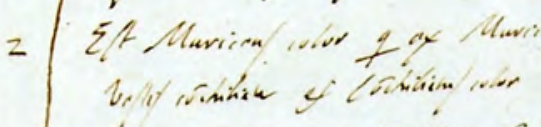

D.

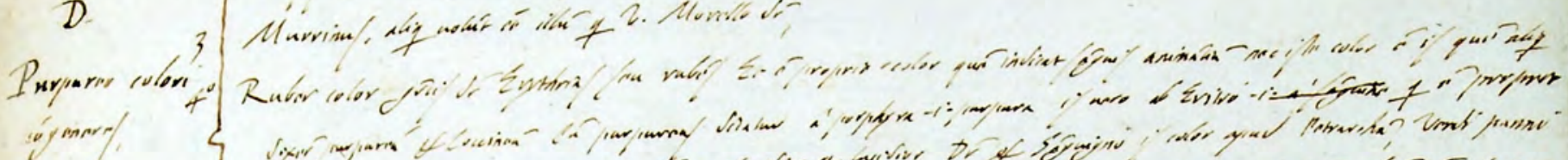

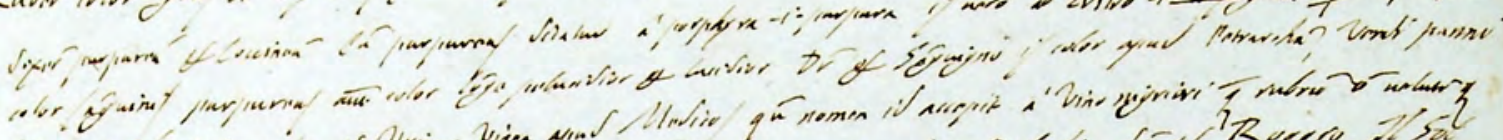

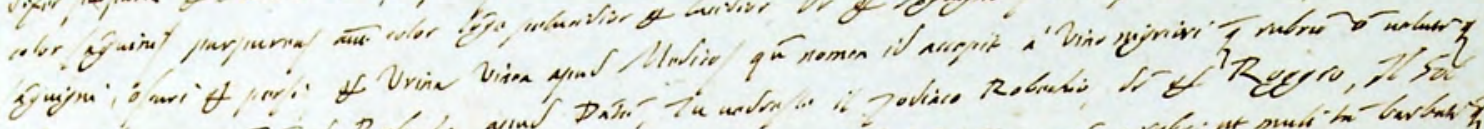

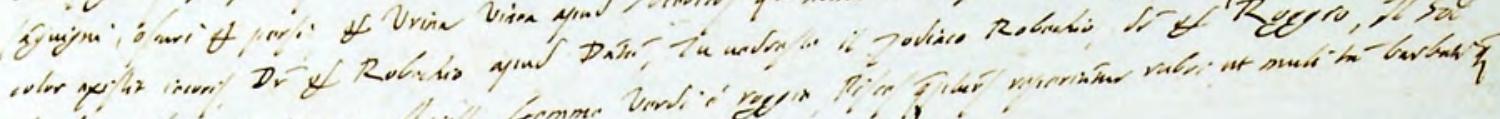

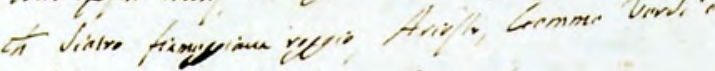

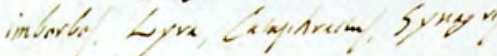

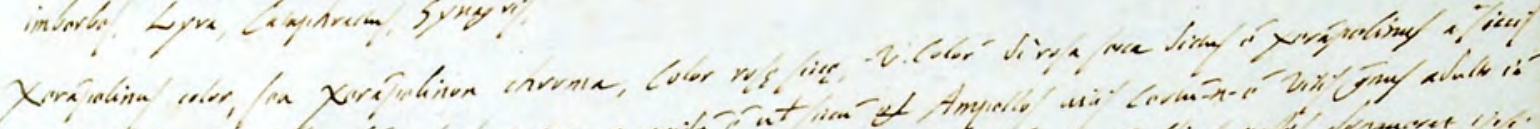

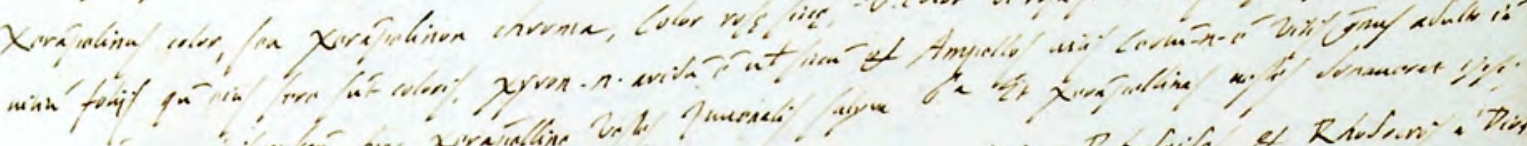

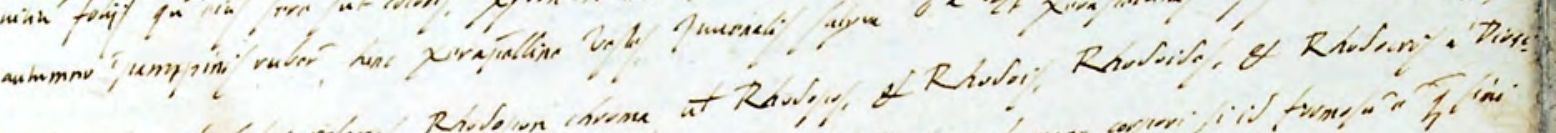

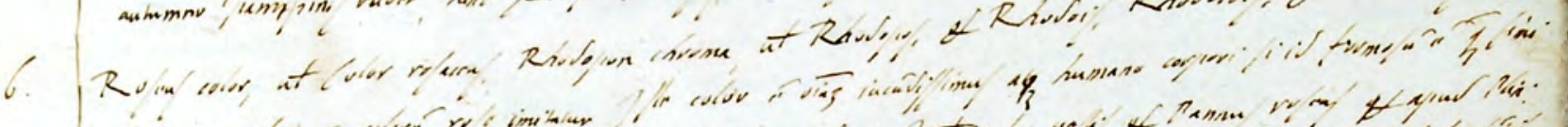

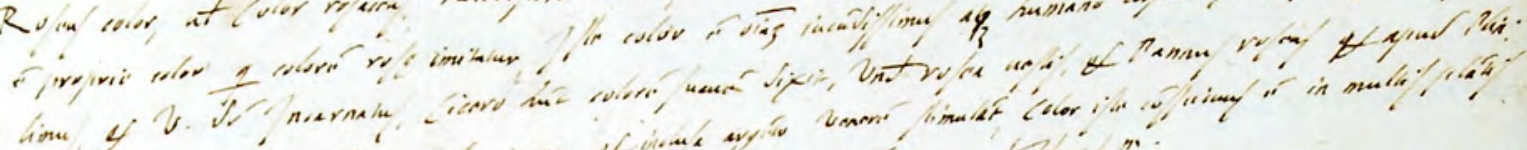

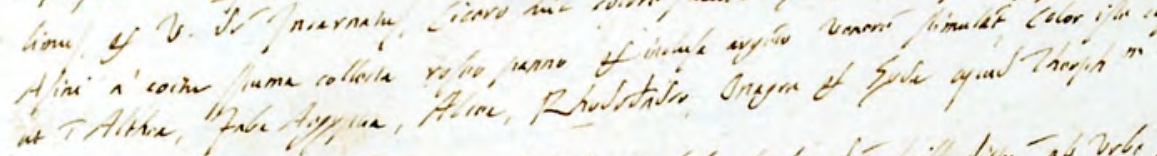

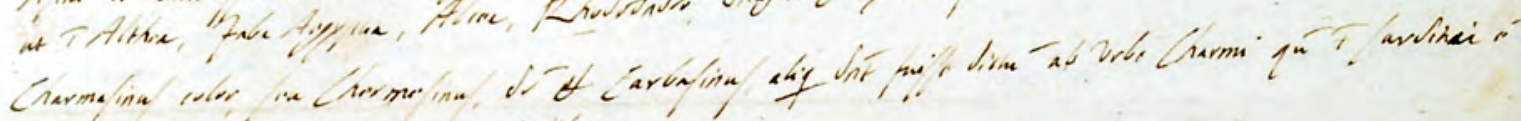

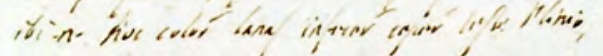

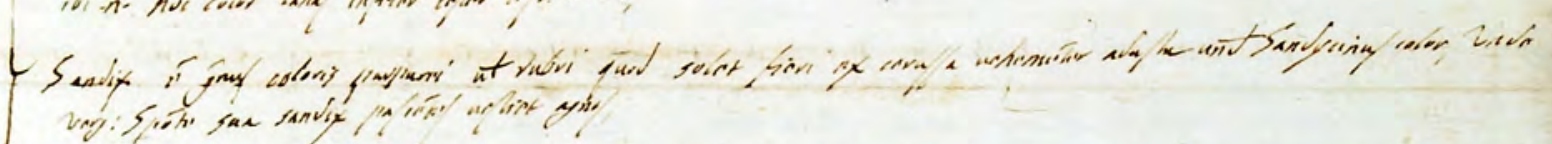

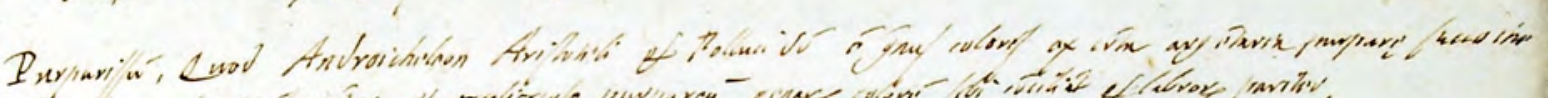

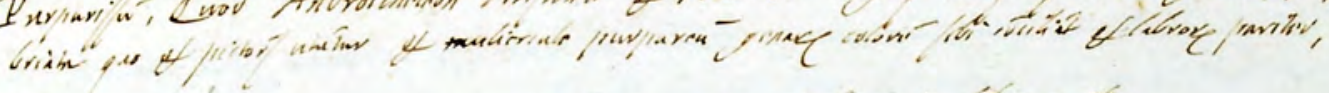

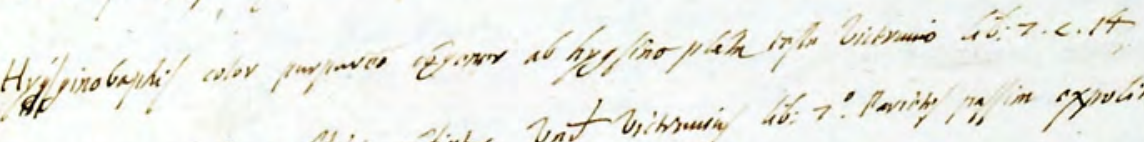

10

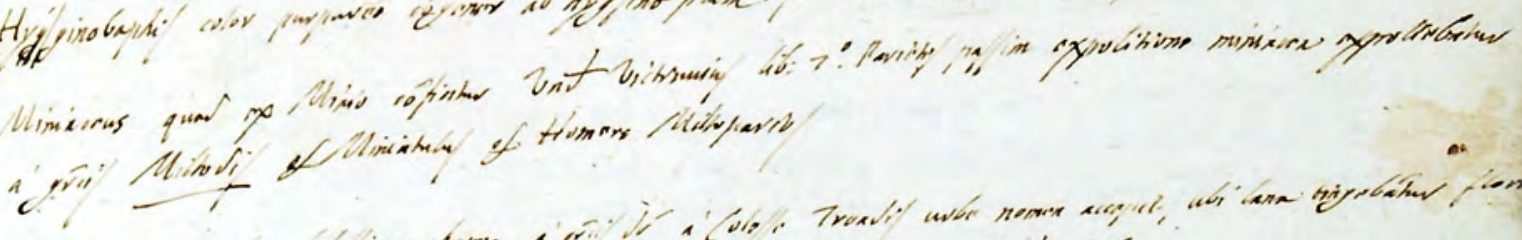

$11^{3}$

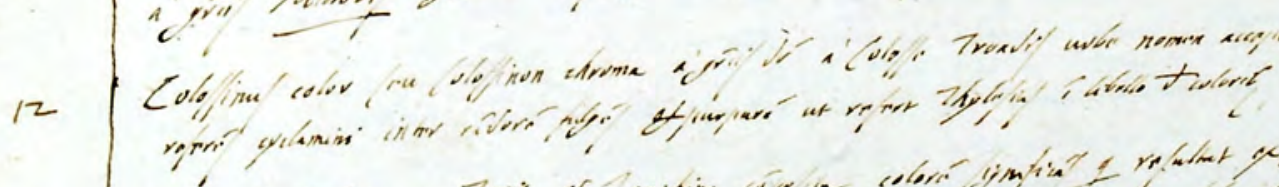

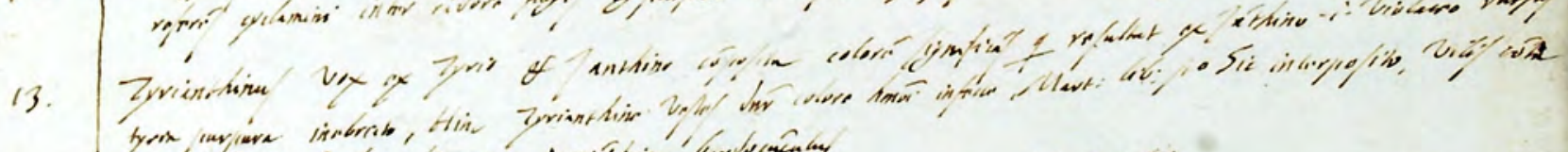

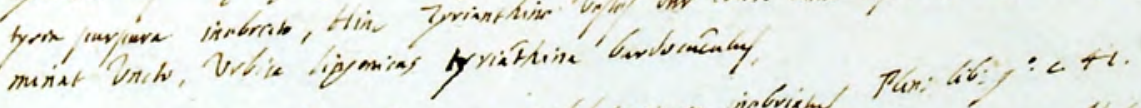

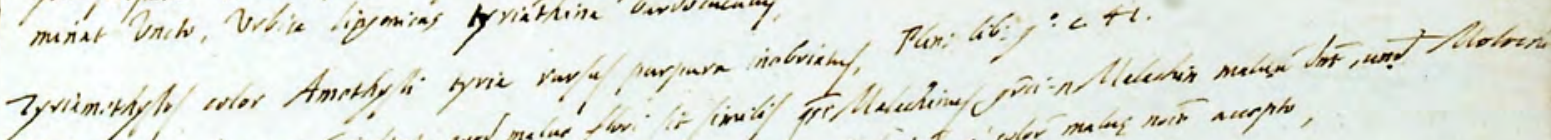

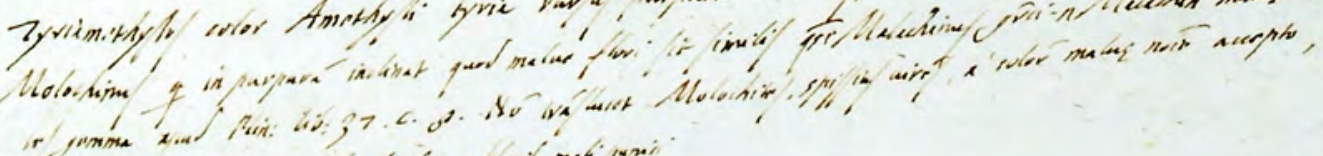

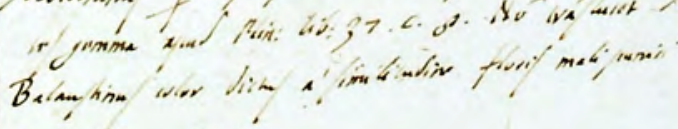

Ex ald vars"

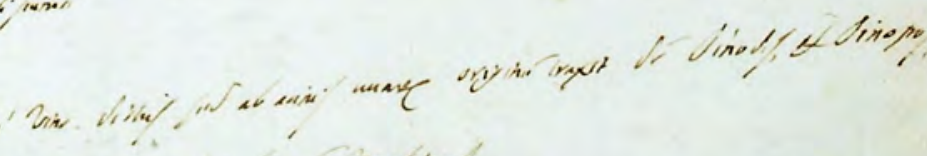

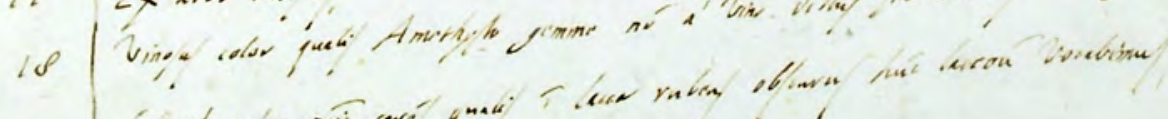

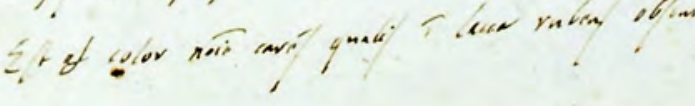



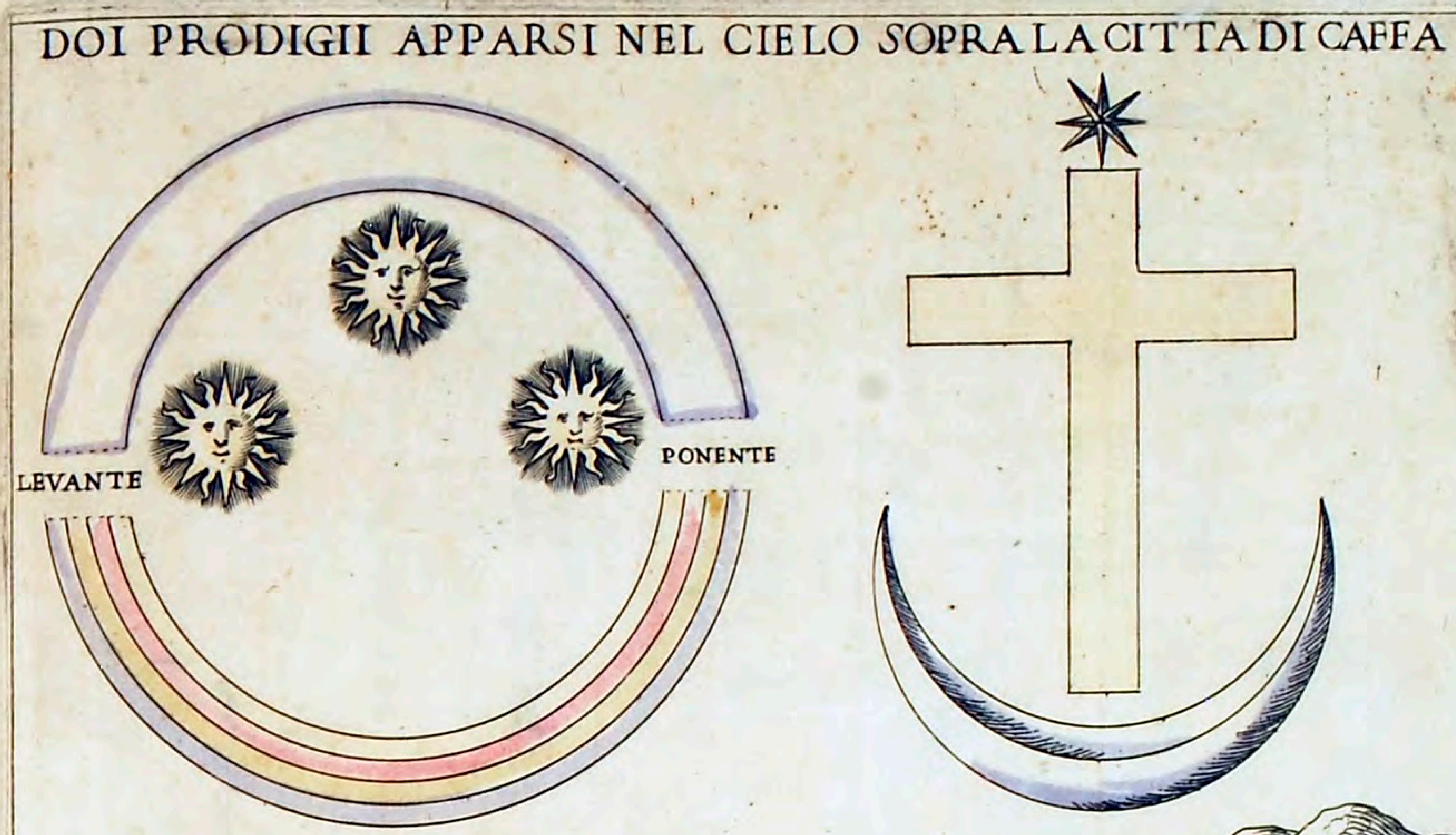
(n) a

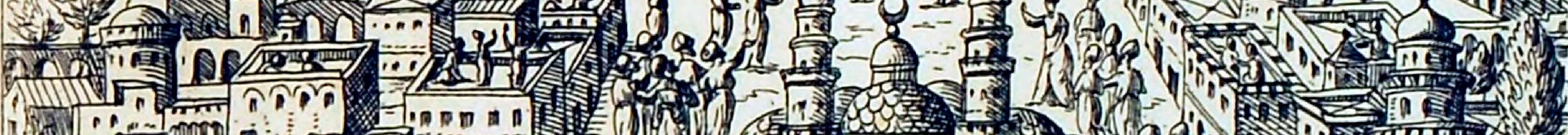
(1)

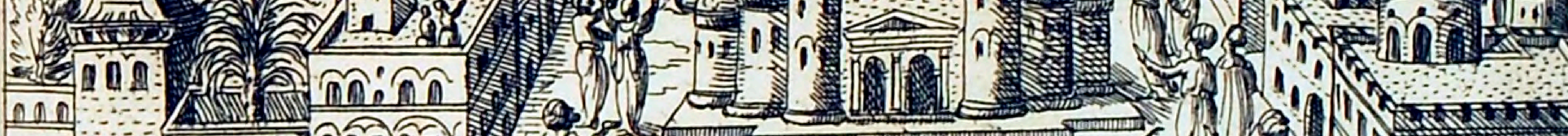

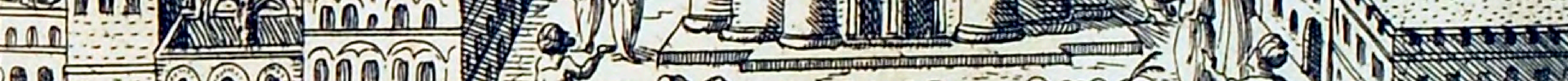
10.m.

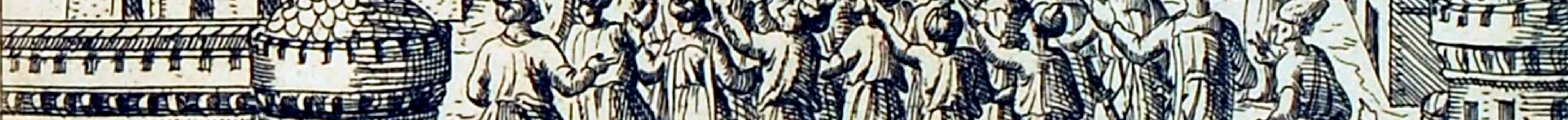

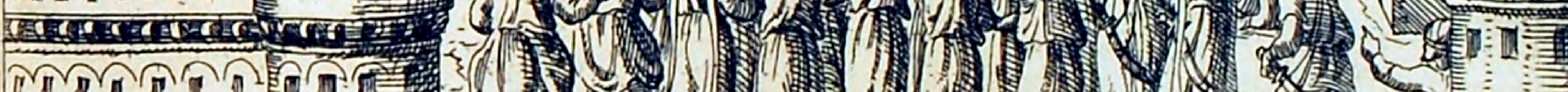
III (2) Adi. 6 di génaro. $s \sigma_{7}$. Sopra guefta Citta di Caffa gia detta Theo do fia, in Tartaria appre $\beta_{0}$ il mare Euxino, doue doián fa el Turco ha menato if chiaui che hapigfiati dall' 7 sola di Scio, fiuiddero tre Solica un circolo intorno, che laparte uperiore

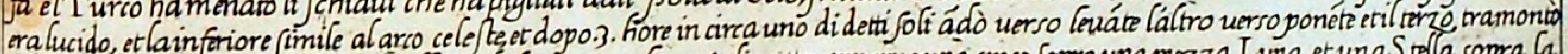

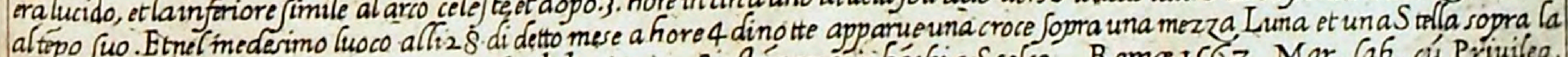
Croce et duro fin alla mattina sempre plendidissimo. Si Stápono in báchi as cello. Roma is6 7. Mar. Cab. á Priuileg. 


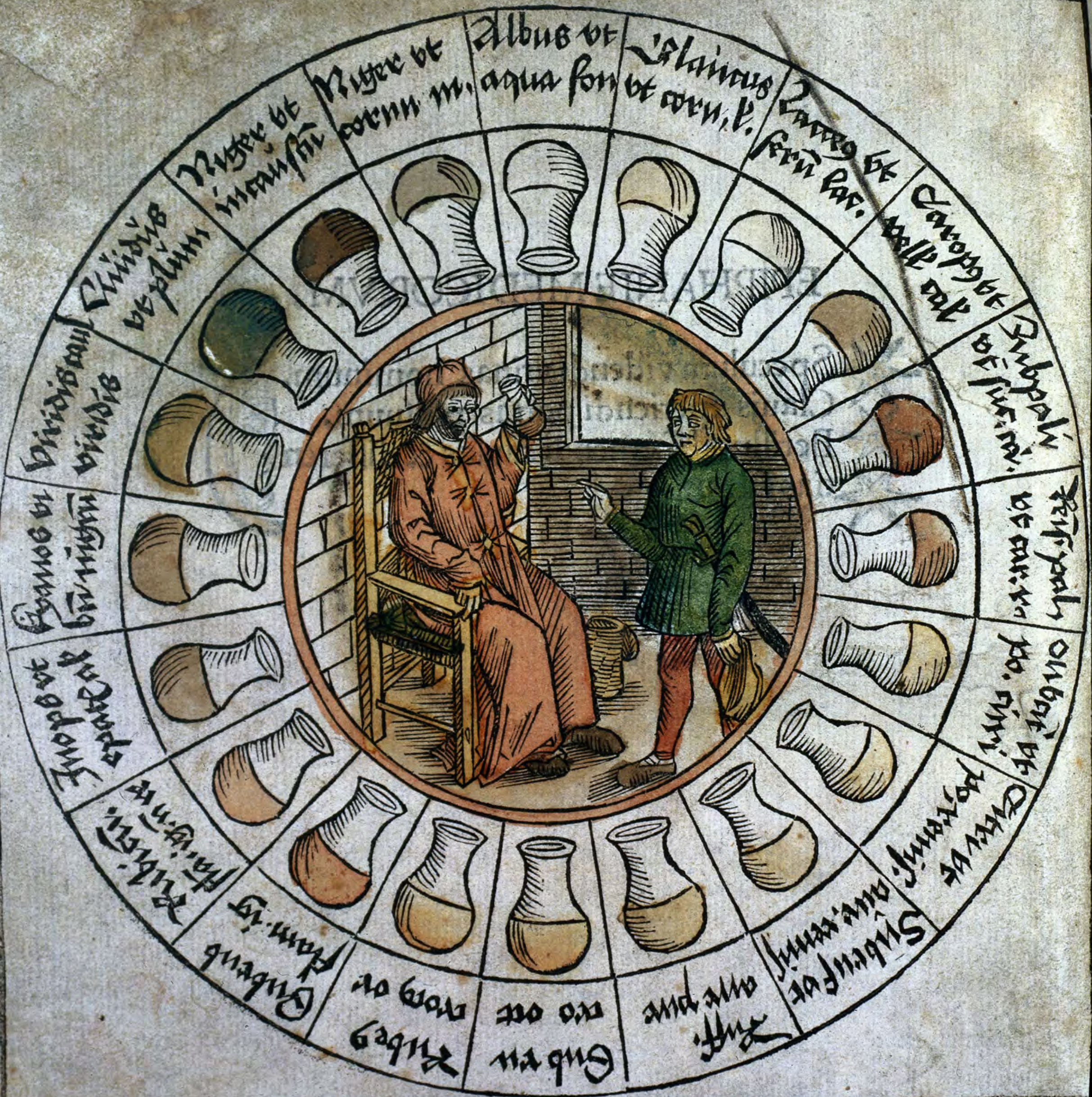




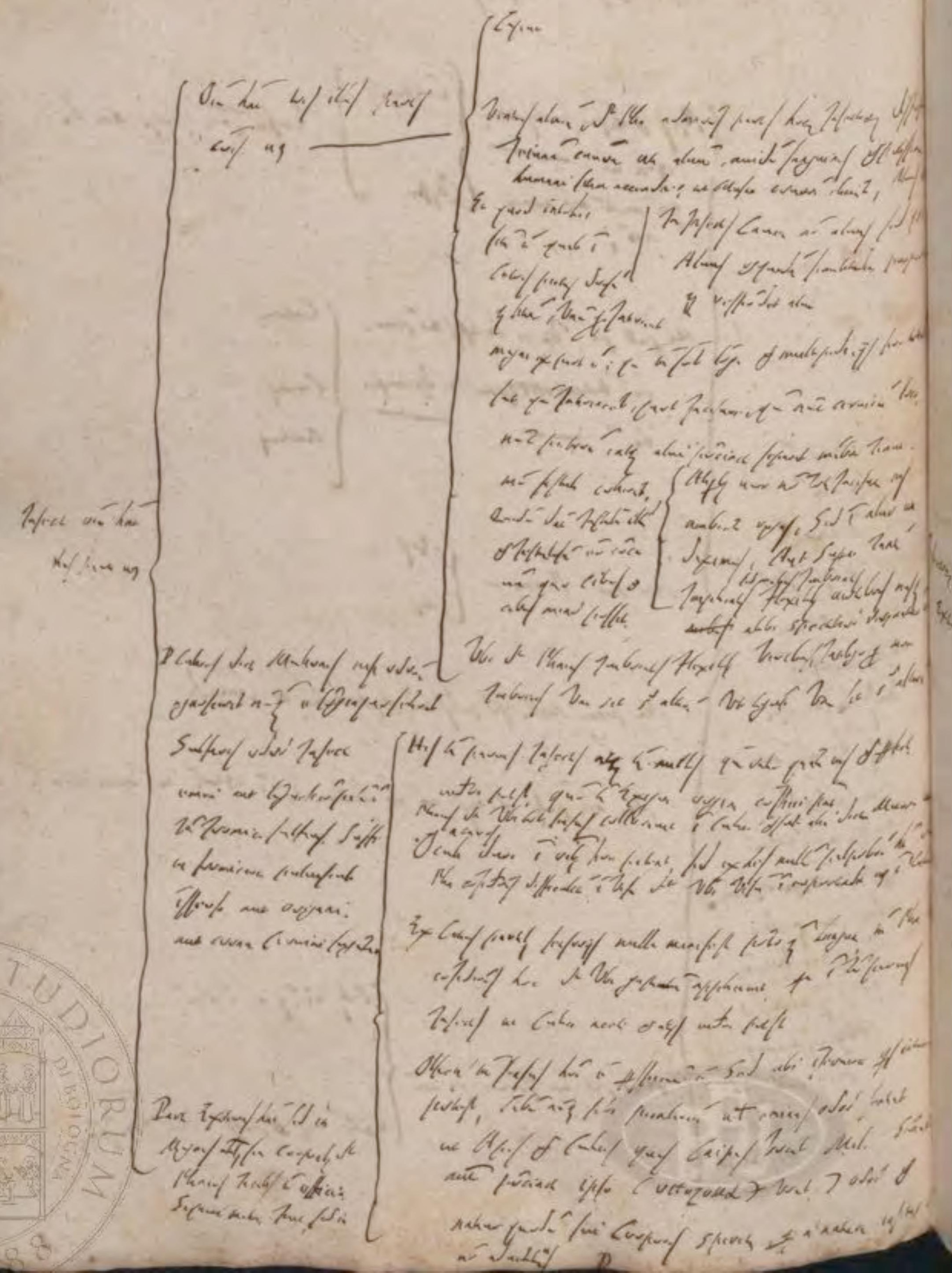




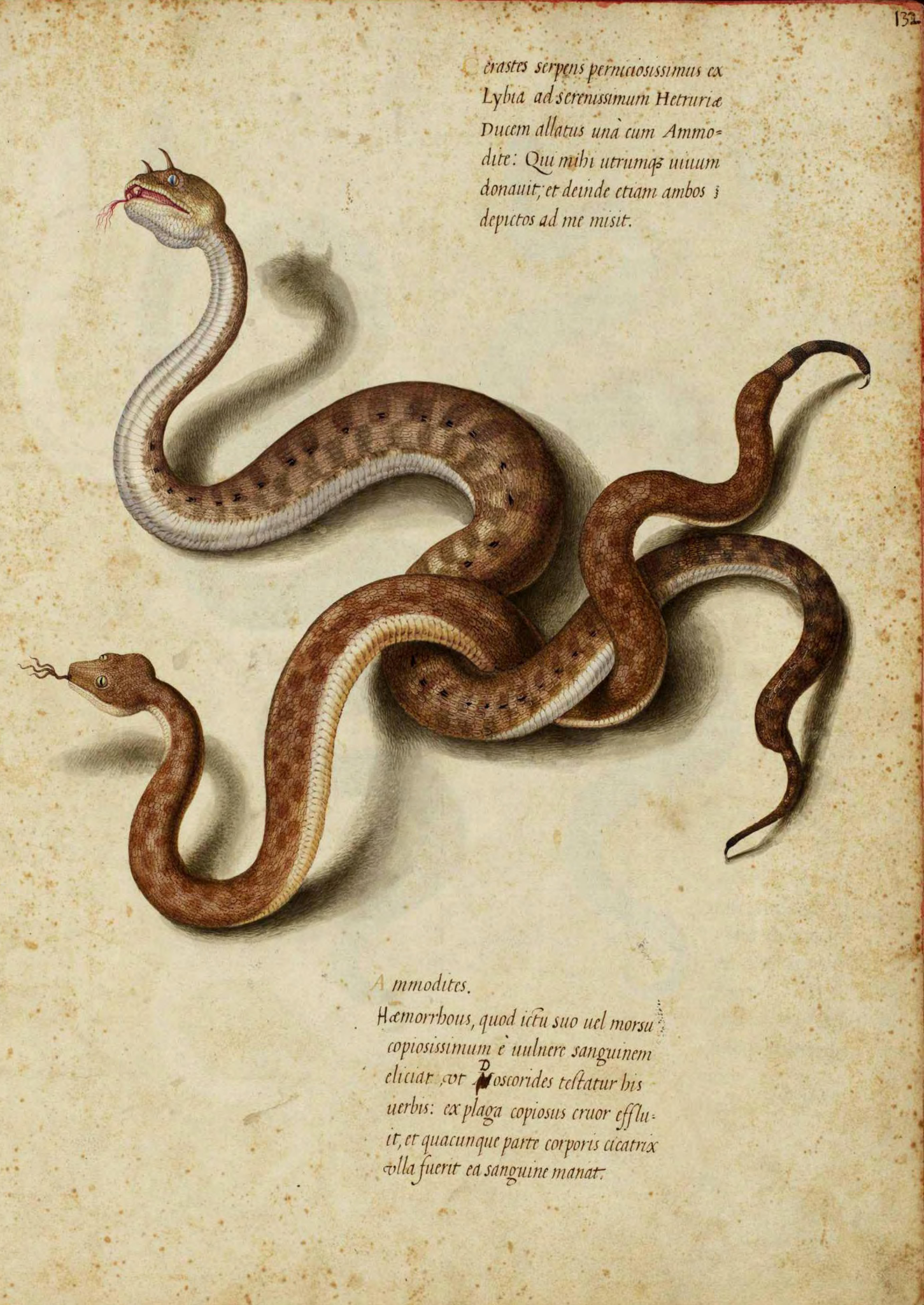




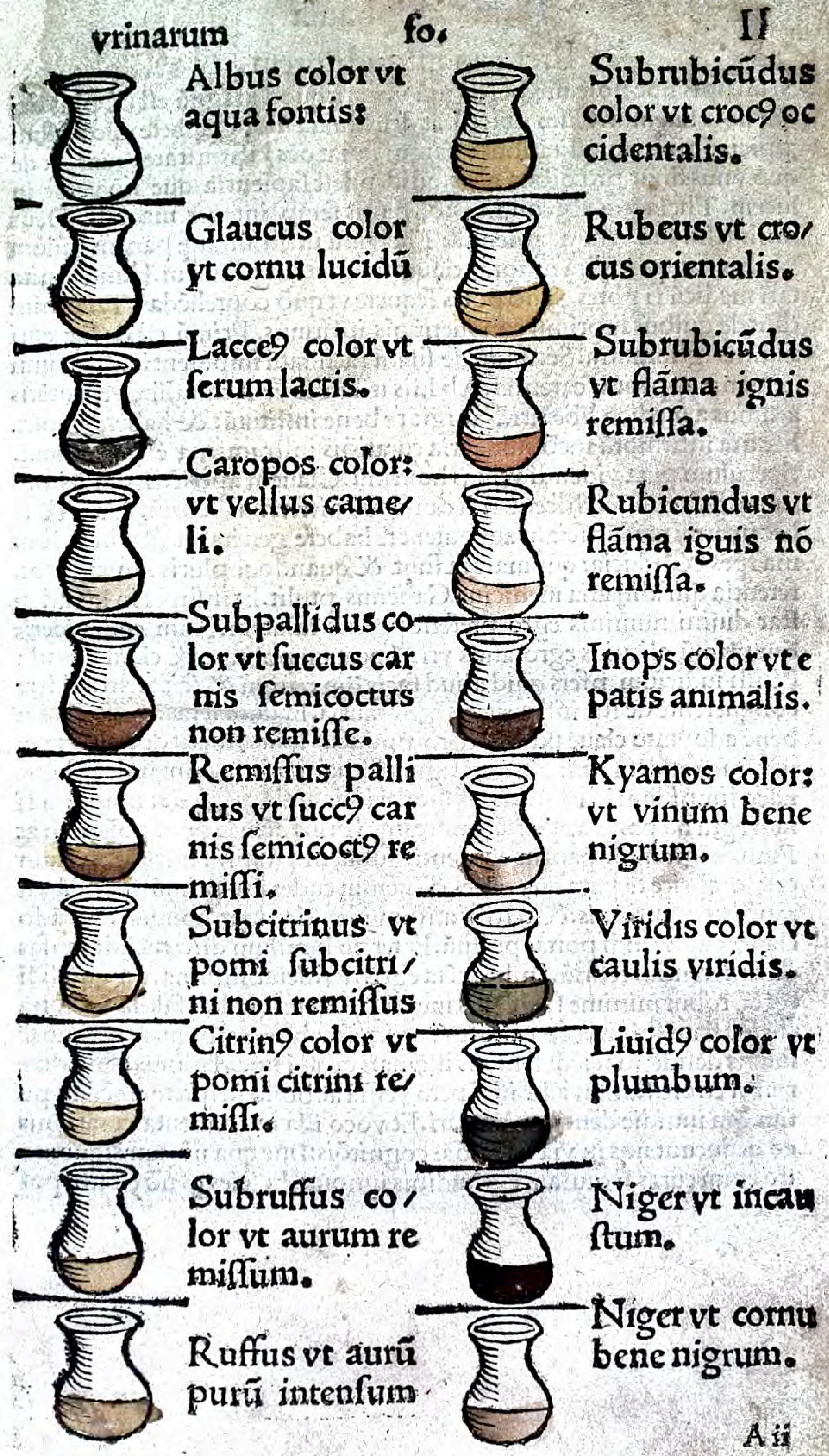




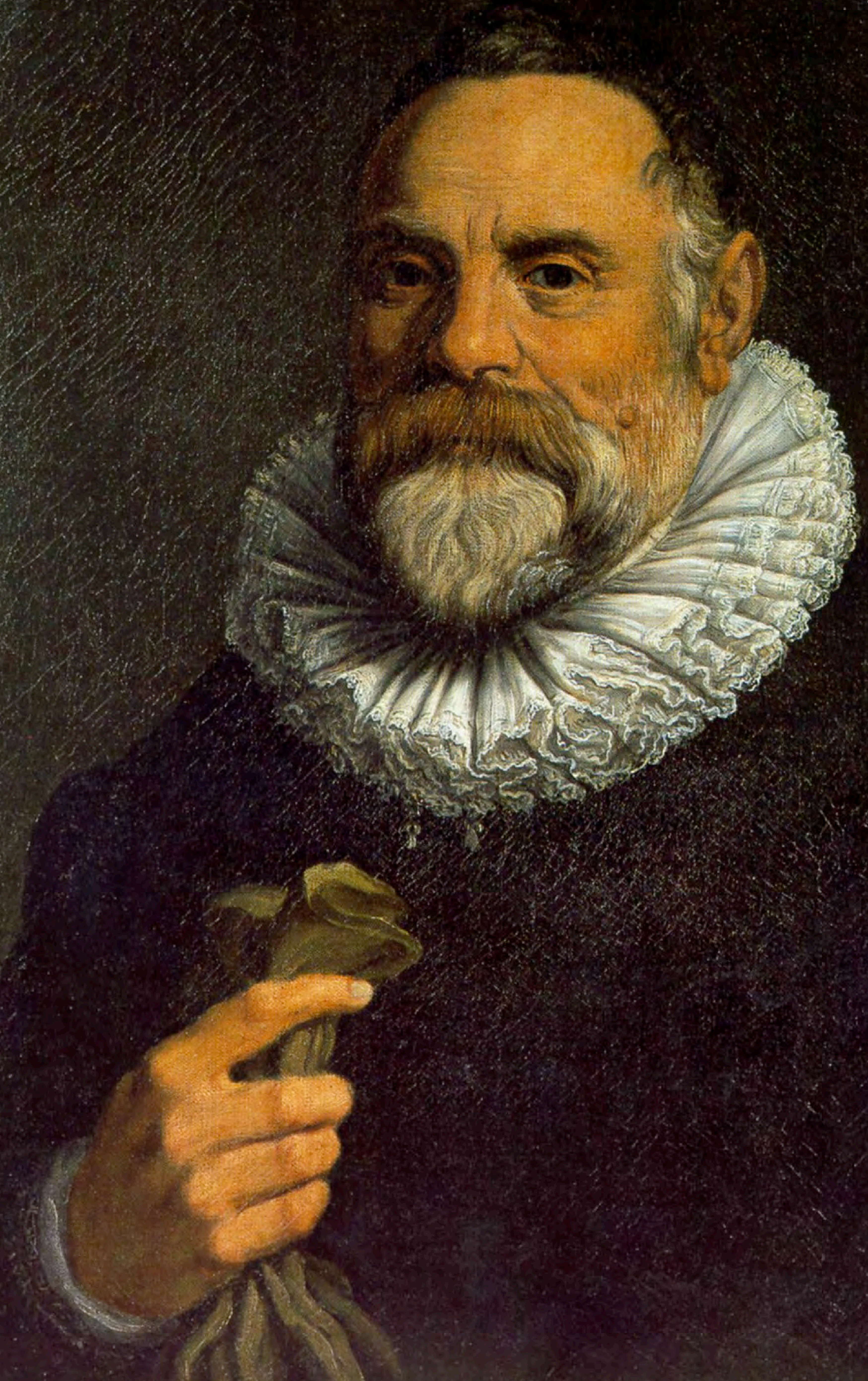




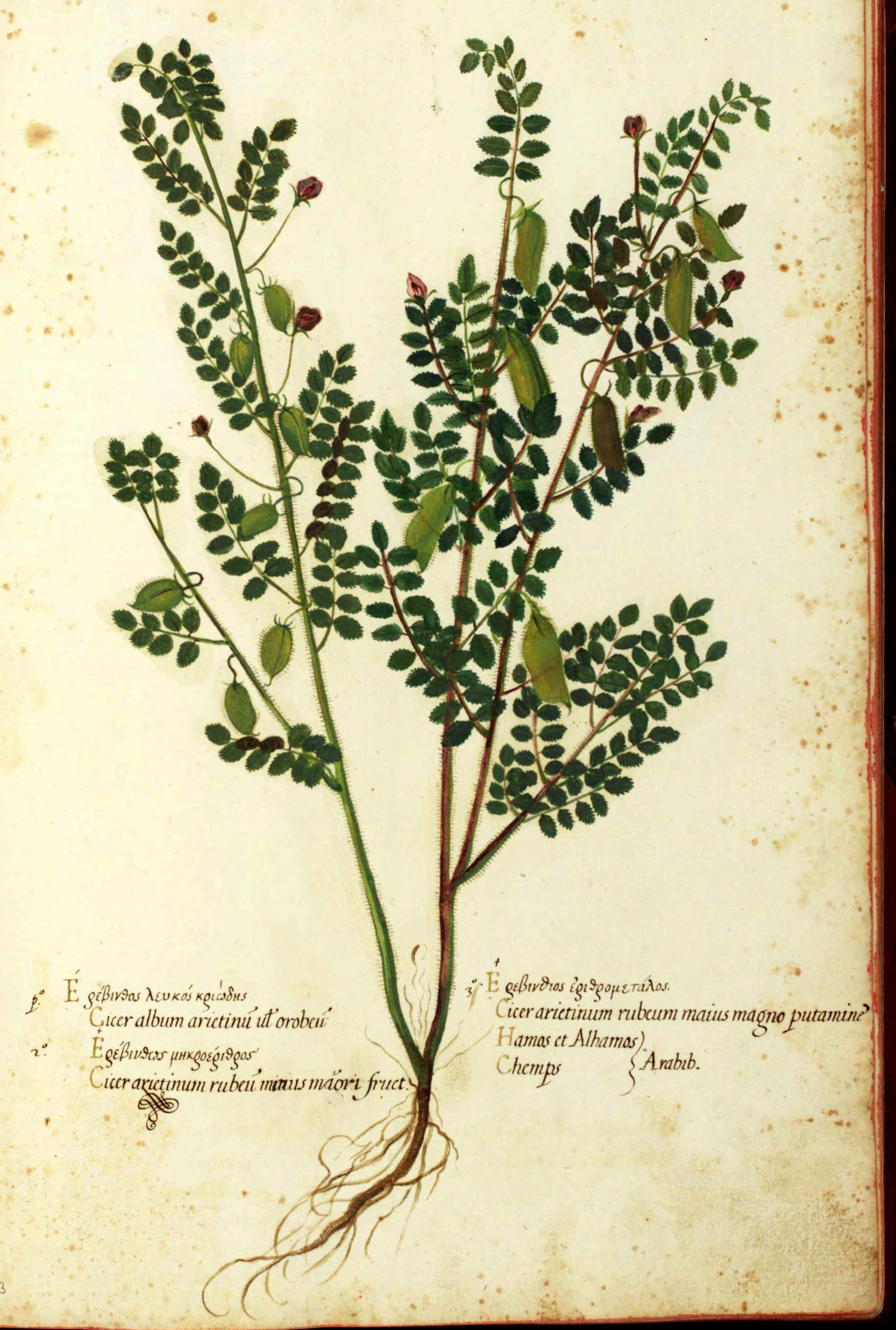

